\title{
Components of near-surface energy balance derived from satellite soundings - Part 1: Noontime net available energy
}

\author{
K. Mallick ${ }^{1}$, A. Jarvis ${ }^{2}$, G. Wohlfahrt ${ }^{3, *}$, G. Kiely ${ }^{4}$, T. Hirano ${ }^{5}$, A. Miyata ${ }^{6}$, S. Yamamoto ${ }^{7}$, and L. Hoffmann ${ }^{1}$ \\ ${ }^{1}$ Environmental Research and Innovation (ERIN), Luxembourg Institute of Science and Technology (LIST), \\ L4422, Belvaux, Luxembourg \\ ${ }^{2}$ Lancaster Environment Centre, Lancaster University, Lancaster LA1 4YQ, UK \\ ${ }^{3}$ Institute of Ecology, University of Innsbruck, 6020 Innsbruck, Austria \\ ${ }^{4}$ Hydrometeorology Research Group, Department of Civil and Environmental Engineering, University College Cork, Ireland \\ ${ }^{5}$ Division of Environmental Resources, Research Faculty of Agriculture, Hokkaido University, Hokkaido, Japan \\ ${ }^{6}$ National Institute for Agro-Environmental Sciences, Tsukuba, Japan \\ ${ }^{7}$ Graduate School of Environmental Science, Okayama University Tsushimanaka3-1-1, Okayama 700-8530, Japan \\ *now at: European Academy of Bolzano, 39100 Bolzano, Italy
}

Correspondence to: K. Mallick (kaniska.mallick@gmail.com)

Received: 27 March 2014 - Published in Biogeosciences Discuss.: 6 August 2014

Revised: 25 November 2014 - Accepted: 15 December 2014 - Published: 23 January 2015

\begin{abstract}
This paper introduces a relatively simple method for recovering global fields of monthly midday (13:30 LT) near-surface net available energy (the sum of the sensible and latent heat flux or the difference between the net radiation and surface heat accumulation) using satellite visible and infrared products derived from the AIRS (Atmospheric Infrared Sounder) and MODIS (MODerate Resolution Imaging Spectroradiometer) platforms. The method focuses on first specifying net surface radiation by considering its various shortwave and longwave components. This was then used in a surface energy balance equation in conjunction with satellite day-night surface temperature difference to derive $12 \mathrm{~h}$ discrete time estimates of surface system heat capacity and heat accumulation, leading directly to retrieval for surface net available energy. Both net radiation and net available energy estimates were evaluated against ground truth data taken from 30 terrestrial tower sites affiliated with the FLUXNET network covering 7 different biome classes. This revealed a relatively good agreement between the satellite and tower data, with a pooled root-mean-square deviation of 98 and $72 \mathrm{~W} \mathrm{~m}^{-2}$ for monthly 13:30 LT net radiation and net available energy, respectively, although both quantities were underestimated by approximately 25 and $10 \%$, respectively, relative to the tower observation. Analysis of the individual shortwave and longwave components of the net ra-
\end{abstract}

diation revealed the downwelling shortwave radiation to be main source of this systematic underestimation.

\section{Introduction}

An important manifestation of climate change is widespread alteration of the composition of the energy balance at the Earth's surface (Trenberth et al., 2009; Wild et al., 2013). Given the importance of being able to predict the consequences of climate change, both measurement and modelling of the components of surface energy balance attract significant attention from a broad range of related scientific disciplines (Stephens et al., 2012). Two such disciplines are hydrology and meteorology, which share a common interest in resolving the balance between sensible, $H$, and latent, $\lambda E$, heat fluxes over a broad range of spatial and temporal scales (Anderson et al., 2012).

Net available energy, $\Phi$, is a core variable used to predict the magnitude of $H$ and $\lambda E$ given that it is defined as the sum of these two fluxes (Wright et al., 1992; Migletta et al., 2009; Anderson et al., 2012), 
$\Phi=\lambda E+H$.

The utility of this definition arises from being able to also specify $\Phi$ as the difference between the net broadband radiation, $R_{\mathrm{N}}$, and the rate of heat accumulation, $G$, below the plain across which $R_{\mathrm{N}}$ is specified,

$\Phi=R_{\mathrm{N}}-G$

Given that $R_{\mathrm{N}}$ is routinely measured using net radiometers, this affords an opportunity to specify $\Phi$ and hence either $H$ or $\lambda E$. For example, in modelling studies $\lambda E$ is invariably specified as a function of $\Phi$ using the ubiquitous equations such as those of Penman (1948) for open water or Monteith (1965) for land surfaces (Mu et al., 2011; Mallick et al., 2014a). Despite being the rate of change of heat stock in terrestrial environments, $G$ is often interpreted as the "ground heat flux", and attempts to measure this using heat flux plates are commonplace (Mayocchi and Bristow, 1995; Sauer and Horton, 2005; Heitman et al., 2010). These measurements prove somewhat less reliable than $R_{\mathrm{N}}$ due to greater spatial heterogeneity in ground heat uptake (Gao et al., 1998; Tittebrand and Berger, 2009; Verhoef et al., 2012) allied to the fact that significant heat capacity resides in other elements of the land surface (Ochsner et al., 2007). As a result, $G$ proves problematic in surface energy balance studies and is either ignored (Foken et al., 2006; Foken, 2008) or treated somewhat superficially (Choudhury, 1987), despite being significant under a broad range of conditions (Santanello and Friedl, 2003; Ochsner et al., 2007). Large-scale estimates of $G$ are useful in the context of regional and global evapotranspiration modelling and for verification of regional and global circulation models (Kergoat et al., 2011).

The arrival of satellite retrievals for many of the components of $R_{\mathrm{N}}$ has opened up opportunities to develop largescale estimates of this variable and hence $\lambda E$ (Batra et al., 2006; $\mathrm{Mu}$ et al., 2007, Anderson et al., 2012). For example, retrievals for the components of $R_{\mathrm{N}}$ have been available through the International Satellite Cloud Climatology Project (ISCCP) (Pinker and Laszlo, 1992; Stephens et al., 2012), the Earth Radiation Budget Experiment (ERBE) (Priestley et al., 2011), and the Clouds and the Earth's Radiant Energy System (CERES) (Mlynczak et al., 2011; Chen et al., 2013) onboard NASA's Earth Observing System (EOS) and Tropical Rainfall Measuring Mission (TRMM) satellites (Wielicki et al., 1998). Several studies have reported the estimation of $R_{\mathrm{N}}$ using a combination of MODIS (MODerate Resolution Imaging Spectroradiometer) atmospheric and land products over the USA, China and India (Cai et al., 2007; Mallick et al., 2009; Bisht and Bras, 2010, 2011) or NOAA-14 (National Oceanic and Atmospheric Administration) data over the Tibetan Plateau (Ma et al., 2002).

Unfortunately, in the absence of direct observations of $G$ at spatial scales and coverage of satellite $R_{\mathrm{N}}$, retrievals for
$\Phi$ have had to rely on the parameterisation of $G$ using surface temperature, albedo and vegetation index information (Bastiaanssen et al., 1998; Batra et al., 2006) or by assigning some fixed proportion of $R_{\mathrm{N}}$ (Choudhury, 1987; Humes et al., 1994) in satellite-based surface energy balance models (Mecikalski et al., 1999; Anderson et al., 2012). However studies by Murray and Verhoef (2007), Hsieh et al. (2009) and recently Verhoef et al. (2012) also demonstrated that $G$ is, by definition, a highly dynamic quantity, and that the ratio $G / R_{\mathrm{N}}$ can range anywhere from 0.05 to 0.50 depending on the time of day, soil moisture and thermal properties, and vegetation density. Therefore, methods that are able to provide defensible estimates of $G$ in conjunction with $R_{\mathrm{N}}$ would clearly be of great benefit to this area for determining $\Phi$ directly from satellite data and without relying unduly on any offline calibration. In this paper we present a method for retrieving $R_{\mathrm{N}}$ and $\Phi$ based on exploring both satellite radiance data and day-night surface temperature difference. The approach is necessarily simple in order to avoid over-reliance on models in the pre-processing and to reflect the fact that the focus of this work is the production of satellite estimates of monthly midday (13:30; all times listed are in local time, LT) $\Phi$ for use in a simple Bowen ratio (Bowen, 1926) $\lambda E$ specification framework as detailed in a companion paper by Mallick et al. (2014b) (we refer to this as M2 hereafter). Taking advantage of the extensive network of terrestrial eddy covariance tower sites (Baldocchi et al., 2001) which record direct measurements of $R_{\mathrm{N}}, H$ and $\lambda E$, we use these measurements to derive independent non-radiative estimates of $\Phi$ in order to critically evaluate our satellite estimates of this quantity.

The method we present here for estimating $R_{\mathrm{N}}$ contrasts with more sophisticated model-based approaches which attempt to accommodate the complexity of atmospheric radiative transfer explicitly (e.g. Fouquart and Bonnel, 1980; Mlawer et al., 1997; Bisht and Bras, 2010, 2011; Hou et al., 2014). There are several reasons for adopting this stance. Firstly, the estimates of $R_{\mathrm{N}}$ need to be in agreement with the simple dynamic energy balance used to accommodate $G$ when specifying $\Phi$. Secondly, we believe it to be important that the complexity of the methods used here is commensurate with those methods used in the simple Bowen ratio approach as described in M2. Related to this, we have tried to restrict the approach to largely using only AIRS (Atmospheric InfraRed Sounder) data which provide the satellite soundings required for the Bowen ratio estimates. This single-platform approach is adopted to ensure the estimates do not suffer unduly from blending different data sources. Finally, as is the case with this method, complex radiative transfer approaches are also prone to the effects of uncertainty (Betts et al., 1993; Morcrette, 2002; Seidel et al., 2010), and therefore the parsimony implicit in the methods used here may be seen as advantageous. 


\section{Methodology}

\subsection{Satellite data sets}

In the present study, two different data sources were used for the estimation of $R_{\mathrm{N}}$ and $\Phi$, AIRS and MODIS. The AIRS sounder is carried by NASA's Aqua satellite, which was launched into a Sun-synchronous low Earth orbit on 4 May 2002 as part of NASA's Earth Observing System. It gives near-global coverage twice daily at 01:30-13:30 LT from an altitude of $705 \mathrm{~km}$. Level 3 standard monthly day-night data products of air temperature and relative humidity profiles, cloud cover fraction, surface emissivity, near-surface air temperature, and surface-skin temperature and columnar total precipitable water at $1^{\circ} \times 1^{\circ}$ spatial resolution were obtained for 2003 from the online data archive of AIRS, distributed through NASA Mirador data holdings (http://mirador.gsfc. nasa.gov/). The monthly products are simply the arithmetic mean, weighted by counts, of the daily data of each grid box. The multi-day merged products have been used here because the IR retrievals are not cloud-proof and the multi-day product gave decent spatial cover in light of the missing cloudysky data. The data products were obtained in hierarchical data format (HDF4) along with their latitude-longitude projection. It is also important to mention that the daily $1^{\circ}$ data contain orbital gaps and cloud contamination. In the 8-day data the co-incident land surface temperature in both the day and night pass was missing, and the atmospheric soundings were also missing in many places. It is the monthly data set where the soundings as well as both the day-night land surface temperatures were available and the data have complete global coverage.

We have used the MODIS Aqua atmospheric product data sets (MYD08_D3) (http://modis-atmos.gsfc.nasa.gov/index. html) at $1^{\circ} \times 1^{\circ}$ spatial resolution for extracting the solar zenith angle field. AIRS data do not contain any surface albedo field. For generating the surface albedo fields we used narrowband surface reflectances from combined MODIS Terra-Aqua 16-day data (MCD43C4) products acquired from the MODIS data archive (http://ladsweb.nascom. nasa.gov/data/search.html). The native spatial resolution of the MCD43C4 data sets is $0.05^{\circ}$. Therefore, all the narrowband surface reflectances were first resized into $1^{\circ}$ by $1^{\circ}$ to make them compatible with the AIRS spatial resolution and then the broadband surface albedo was generated from the narrowband reflectances following Liang et al. (1999) (presented in next section). It is important to mention that MODIS global albedo product (MCD43C3) contains bi-hemispherical reflectance (white-sky albedo) and directional hemispherical reflectance (black-sky albedo). Bluesky albedo can be determined by weighting the white- and black-sky albedo with diffuse skylight fraction, which is a function of the aerosol optical depth and solar zenith angle. Look-up-table-based aerosol information and parameters are needed to convert the reflectances into the blue-sky albedo.
But there are established formulations (Liang et al., 1999; Liang et al., 2002) to directly convert the narrowband reflectances into the broadband visible albedo that does not depend on any atmospheric variables and look-up tables, and therefore narrowband surface reflectances are used in the present study.

One of the core objectives of the work is to explore the potential of atmospheric sounding data. AIRS is the only dedicated sounder available which can be explored to address the objectives in the paper. MODIS also has soundings, but it was not designed for this and only has low-quality air temperature soundings. Coarse spatial resolution of AIRS would introduce many difficulties when it comes to the evaluation, but the most important aspect of the two companion papers (we refer to the current one as M1) is to introduce the possibility of using atmospheric sounding data as a means of observing surface energy fluxes (the companion paper on latent and sensible heat flux, M2). We have restricted $\Phi$ derivation to (largely) AIRS data (we used MODIS albedo because AIRS does not contain any albedo field) in order to exploit a single platform for the entire framework. We would also emphasise that the $\Phi$ retrievals are on one time slot per day for 13:30 LT, which is a standard for the studies that use polarorbiting satellites.

\subsection{Net radiation}

The approach for estimating $R_{\mathrm{N}}$ uses the AIRS radiation products, although we have also made use of the MODIS surface reflectance and solar zenith angle products where necessary. $R_{\mathrm{N}}$ is generated by considering the following balance between net shortwave $\left(R_{\mathrm{NS}}\right)$ and longwave $\left(R_{\mathrm{NL}}\right)$ radiation at or near the Earth's surface,

$R_{\mathrm{N}}=R_{\mathrm{NS}}+R_{\mathrm{NL}}=(1-\alpha) R_{\mathrm{S} \downarrow}+R_{\mathrm{L} \downarrow}-R_{\mathrm{L} \uparrow}$,

where $\alpha$ is the surface albedo, $R_{\mathrm{L} \downarrow}$ and $R_{\mathrm{L} \uparrow}$ are the downwelling and upwelling thermal radiative fluxes, and $R_{\mathrm{S} \downarrow}$ is the downwelling shortwave radiative flux (all fluxes specified in $\mathrm{W} \mathrm{m}^{-2}$ ). Our chosen reference level for $R_{\mathrm{N}}$ is the near surface given that this corresponds to the flux-based tower estimates we used in the evaluation. Therefore, surface $R_{\mathrm{S} \downarrow}$ was estimated from its top-of-atmosphere clear-sky counterpart $R_{\mathrm{S} 0 \downarrow}$ and AIRS cloud cover fraction $(f)$ following Hildebrandt et al. (2007),

$R_{\mathrm{S} \downarrow}=(1-f) \tau_{\mathrm{A}} R_{\mathrm{S} 0 \downarrow}$,

where $\tau_{\mathrm{A}}$ is the clear-sky transmissivity of the atmosphere, which we assume is 0.75 (Cano et al., 1986; Thornton and Running, 1999; Hildebrandt et al., 2007; Gubler et al., 2012). Although clearly a simplification, a constant clear-sky transmissivity is widely used (e.g. Massaquoi, 1988; Bindi et al., 1992; Choudhury, 2001; Hildebrandt et al., 2007; Mallick et al., 2009) in recognition of the absence of robust alternatives. In addition, exploiting the AIRS cloud cover fraction data in 
Eq. (2) should help accommodate the effects of variations in both the aerosol optical depth (Kaufman and Koran, 2006; Quass et al., 2010) and atmospheric water vapour (Adhikari et al., 2006).

The terrestrial surface albedo was generated using the MODIS Aqua-Terra surface reflectances $r_{i}$ following Liang et al. (1999),

$\alpha=\sum_{i=1}^{N} p_{i} r_{i}+0.0036$,

where $r_{i}$ are the mid-point reflectances within the $0.62-$ $0.67,0.841-0.876,0.459-0.479,1.230-1.250,1.628-1.653$, $1.628-1.653$, and $2.105-2.155 \mu \mathrm{m}$ wavelength bands and $p_{i}$ are the weightings for each wavelength bands taken as $p_{i}=[0.3973 ; 0.2382 ; 0.3489 ;-0.2655 ; 0.1604 ;-0.0138$; 0.0682] (Liang et al., 1999, 2002). The albedo of the ocean varies according to the cosine of solar zenith angle (Jin et al., 2004). Given that the oceanic surface reflectances are not available in either MODIS or AIRS, a constant albedo of 0.04 was assumed for oceans as satellite radiances are nadir.

Many of the longwave components of the radiative balance are very closely related to the raw IR radiances being measured by AIRS. Because these are not in the public domain, we have attempted to recover them as follows, although in future we would anticipate using the raw IR radiances more directly if possible. $R_{\mathrm{NL}}$ was calculated as

$R_{\mathrm{NL}}=R_{\mathrm{L} \downarrow}-R_{\mathrm{L} \uparrow}=\varepsilon_{\mathrm{C}} \varepsilon_{\mathrm{S}} \sigma T_{\mathrm{C}}^{4}-\varepsilon_{\mathrm{S}} \sigma T_{\mathrm{S}}^{4}$,

where $\sigma$ is the Stefan-Boltzmann constant $\left(5.67 \times 10^{-8} \mathrm{~W}\right.$ $\left.\mathrm{m}^{-2} \mathrm{~K}^{-4}\right), T_{\mathrm{c}}$ is the columnar air temperature, and $\varepsilon_{\mathrm{C}}$ and $\varepsilon_{\mathrm{S}}$ are the column and surface emissivities. Among the different schemes for calculating $\varepsilon_{\mathrm{C}}$ we have used the formulation proposed by Prata (1996) as this appears to be the most reliable (Niemela et al., 2001; Bisht and Bras, 2010, 2011). This scheme uses AIRS total precipitable water $(\xi)(\mathrm{cm})$ information to estimate $\varepsilon_{\mathrm{C}}$ as

$\varepsilon_{\mathrm{C}}=1-(1+\xi) e^{-(1.2+3 \xi)^{0.5}}$.

The columnar air temperature $T_{\mathrm{C}}$ in Eq. (6) is taken as the average of the $2 \mathrm{~m}$ and $1000 \mathrm{hPa}$ pressure level AIRS temperatures in an attempt to reflect a weighting toward the lower troposphere when specifying $R_{\mathrm{L} \downarrow}$. $T_{\mathrm{S}}$ and $\varepsilon_{\mathrm{S}}$ are taken directly from the AIRS skin temperature and surface emissivity products.

\subsection{Surface heat capacity, ground heat flux and net available energy}

The definition of $G$ stems from consideration of the nonsteady-state surface energy balance,

$c \frac{\mathrm{d} T_{\mathrm{S}}(t)}{\mathrm{d} t}=R_{\mathrm{N}}(t)-\lambda E(h)-H(t)=G(t)$, where $c$ is the aggregate surface system heat capacity $\left(\mathrm{MJ} \mathrm{m}^{-2} \mathrm{~K}^{-1}\right)$. The AIRS sounder platform samples twice daily at 01:30 and 13:30 LT. Despite being somewhat coarse, if a discrete time is taken, backward difference approximation of Eq. (8) with a sample interval of $\Delta t=12 \mathrm{~h}$ equivalent to that of the AIRS pass gives

$\Delta T_{\mathrm{S}}(t)=b_{1} R_{\mathrm{N}}(t)+b_{2}$,

where $\Delta T_{\mathrm{S}}$ is the day-night surface temperature change, $b_{1}=\Delta t / c$ and $b_{2}=-\Phi(t) \Delta t / c$. If we assume that the system is approximately in equilibrium over a $24 \mathrm{~h}$ cycle, and that $\Phi \approx 0$ at 01:30 LT (for all 30 sites analysed in this study $\Phi(01: 30$ LT $)<0.05 \Phi(13: 30$ LT); see also Tamai et al., 1998; Mamadou et al., 2014), then this gives the following simultaneous equations:

$$
\begin{aligned}
& \Delta T_{\mathrm{S}}(13: 30)=b_{1} R_{\mathrm{N}}(13: 30)+b_{2}, \\
& -\Delta T_{\mathrm{S}}(13: 30)=b_{1} R_{\mathrm{N}}(01: 30),
\end{aligned}
$$

which can be solved analytically to derive $b_{1}$ and $b_{2}$ and hence $\Phi$ and $c$ for each grid cell in the AIRS global array.

Equation (10) is a coarse approximation of Eq. (8) and hence potentially suffers from a number of deficiencies. Firstly, diurnal symmetry in $\Delta T_{\mathrm{S}}$ is only appropriate when one considers weekly or monthly average behaviour, and that there are no additional heat losses to or gains from stores beyond the domain defined by the single heat capacity $c$. In this study we examined the monthly average behaviour because AIRS only gives partial global coverage on the daily timescale due to both cloud effects and the non-overlapping swath width of the sensor. Interactions with additional longterm heat stores is an issue in systems such as the oceans, where there can be a persistent heat loss/gains to/from deeper water over timescales of weeks to months, although relative to the diurnal fluctuation of stored surface heat this tends to be small (Stramma et al., 1986). Secondly, $\Phi$ can be either positive or negative at 01:30 LT, although it tends to be only a fraction (it never exceeds $5 \%$ of afternoon $\Phi$ ) of its 13:30 LT value due to the supply of relatively low amount of energy at night compared to the day. This may be less true for areas of land in the height of winter with cloud-covered days and over the sea where significant daytime heat accumulation could in part be re-released as night-time latent and sensible heat. Thirdly, Eqs. (9 and 10) attribute the magnitude of the daytime $G$ to the night-time net longwave radiative balance, which is obviously rather uncertain. Fourthly, the air emissivity computation using Prata's equation was developed for the daytime and using it for the night-time emissivity may introduce errors. Finally, all the terms in Eq. (8) are highly dynamic and yet are treated as constant or varying linearly over the $12 \mathrm{~h}$ sample interval. It is difficult to predict what the consequences of this are, as it depends on the pattern of radiative forcing throughout the day, which can vary significantly in both time and space. Some illustrative examples of the theoretical assumptions of Eq. (10a, b) are depicted in 

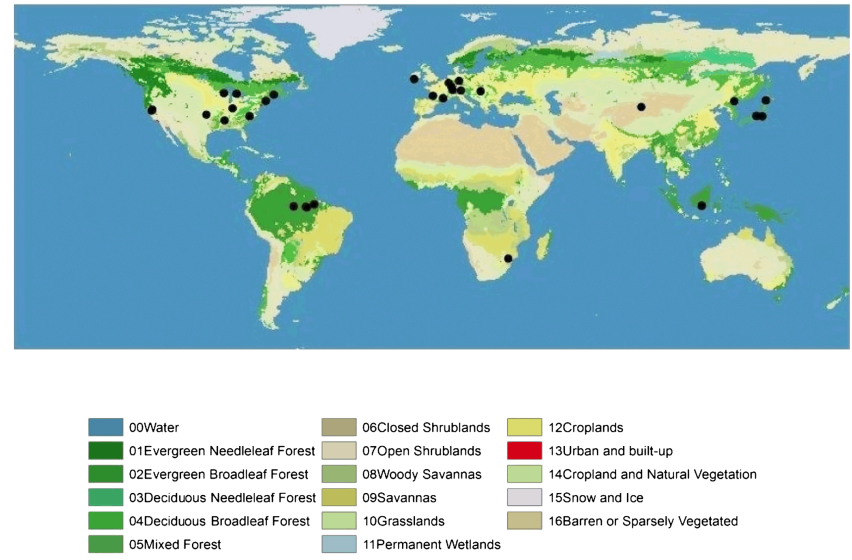

Figure 1. The distribution of the 30 eddy covariance tower sites used for evaluating $R_{\mathrm{N}}$ and $\Phi$.

Figs. 2, 3 and 4. Figure 2 shows the examples of the diurnal symmetry of $T_{\mathrm{S}}$ for clear days in three different seasons where the saw-tooth pattern between noon (13:30 LT) and night (01:30 LT) $T_{\mathrm{S}}$ is evident. This clearly shows how well these two $T_{\mathrm{S}}$ samples capture the dynamic range of the day and hence the discretisation is representative of the daily energy balance. Figure 3a to d illustrate the diurnal evolution of $\Phi$ during three different times of the year (spring, summer and winter) for four broad biome categories (grassland, cropland, forest and savanna), which clearly indicates $\Phi \cong 0$ at 01:3 LT0 and within less than $5 \%$ of afternoon $\Phi$. Lastly, Fig. 4 highlights the two-dimensional relationship between the noontime $G(13: 30 \mathrm{LT})$ and night-time $R_{\mathrm{NL}}(01: 30 \mathrm{LT})$ for the above-mentioned four biomes and the correlation between the two varied between 0.32 and 0.60 , having high correlation over grassland and savanna and moderate correlation over forest and cropland. Despite large differences in the footprint size between $G$ and $R_{\mathrm{NL}}$ measurements, the inverse relationship between the two variables in Fig. 4 clearly indicates the dependence of noontime $G$ on the night-time longwave radiation balance. Therefore, although the theoretical approximations in Eqs. (8) and $(10 \mathrm{a}, \mathrm{b})$ seem to be somewhat coarse and might have a few limitations (as described earlier), but Figs. 2, 3 and 4 indicate strong connectivity between $\Delta T_{\mathrm{S}}, 01: 30 \mathrm{LT} R_{\mathrm{N}}$ (or $R_{\mathrm{NL}}$ ) and 13:30 LT $\Phi$. However, given the structure of the atmosphere and the very small energy fluxes involved, high-latitude $\Phi$ estimates from this method are likely to be problematic in any case.

\subsection{Sensitivity analysis}

A general sensitivity analysis was carried out in order to assess the effects of the propagation of uncertainty onto the estimates of $G, R_{\mathrm{N}}$ and $\Phi$. For this analysis the input terms were assigned uniform prior distributions of $\pm 10 \%$ for all parameters other than temperatures for which $\pm 1 \mathrm{~K}$ uniform prior distributions were assumed. These assumed ranges re-
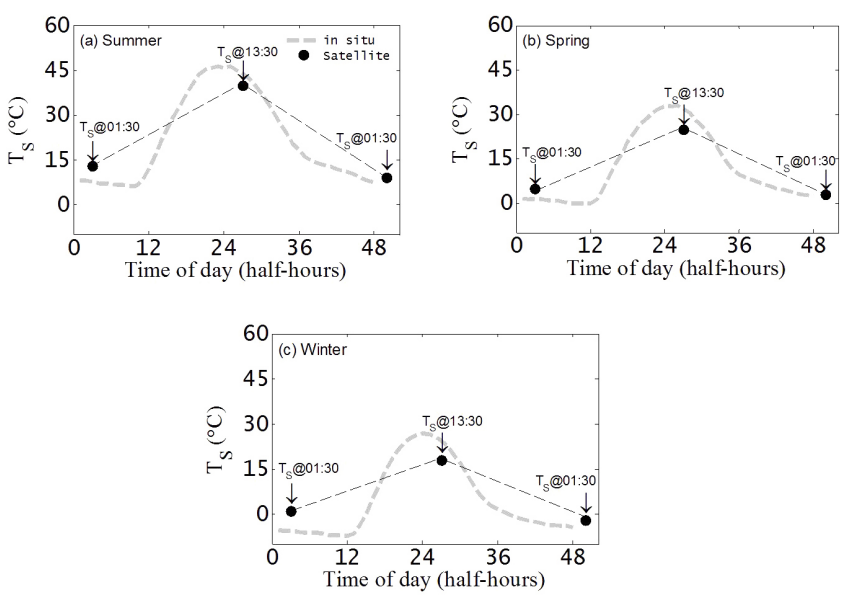

Figure 2. Illustrative examples of in situ monthly diurnal surface temperature $\left(T_{\mathrm{S}}\right)$ and the saw-tooth pattern of monthly satellite midday (13:30 LT) to night-time (01:30 LT) $T_{\mathrm{S}}$ (as hypothesised in Eq. 10) for three different seasons of a year. This shows a linear rise and fall of day-night $T_{\mathrm{S}}$ (dotted black line) or vice versa and indicates $\Delta T_{\mathrm{S}}$ symmetry. This also shows how well the two $T_{\mathrm{S}}$ samples capture the dynamic range of the day and hence the discretisation is representative of the daily energy balance. The examples in Fig. 2 are shown with half-hourly data.

semble the stated uncertainties as given in the AIRS support literature (Aumann et al., 2003; Hearty et al., 2014). The sensitivity of each output to each input was calculated assuming an average, locally linear sensitivity. These were expressed as the change in output per unit change in input, normalised by the median value of each. Only absolute sensitivities $>0.1$ were considered significant. The standard deviations of the estimated distributions of $G, R_{\mathrm{N}}$ and $\Phi$ were used as the summary statistic for the measurement uncertainty of the proposed methodology.

\subsection{Evaluation of $R_{\mathrm{N}}$ and $\Phi$}

To evaluate the satellite values of $R_{\mathrm{N}}$ and $\Phi$, we have made use of the extensive FLUXNET terrestrial tower network (Baldocchi et al., 2001). Clearly, there is a scale conflict here, with the satellite retrievals being $1^{\circ}$ whilst the individual tower observations are for scales of the order of $1 \mathrm{~km}$ or less. The tower $R_{\mathrm{N}}$ are from the broadband net radiometer sensors located on each tower. In the absence of reliable measures of $G$ at the tower scale, and in order to derive genuinely independent measures of $\Phi$ against which to evaluate the satellite data, we have taken the tower net available energy as the sum of the measured sensible and latent heat flux, i.e. Eq. (1). Thereby we have assumed that the eddy covariance flux measurements are able to close the energy balance (i.e. $R_{\mathrm{N}}-G=\lambda E+H$ ), the implications of which will be discussed below. We have chosen 30 sites covering a broad range of geographical locations selected from 7 land cover types, including evergreen broadleaf forest (EBF), 

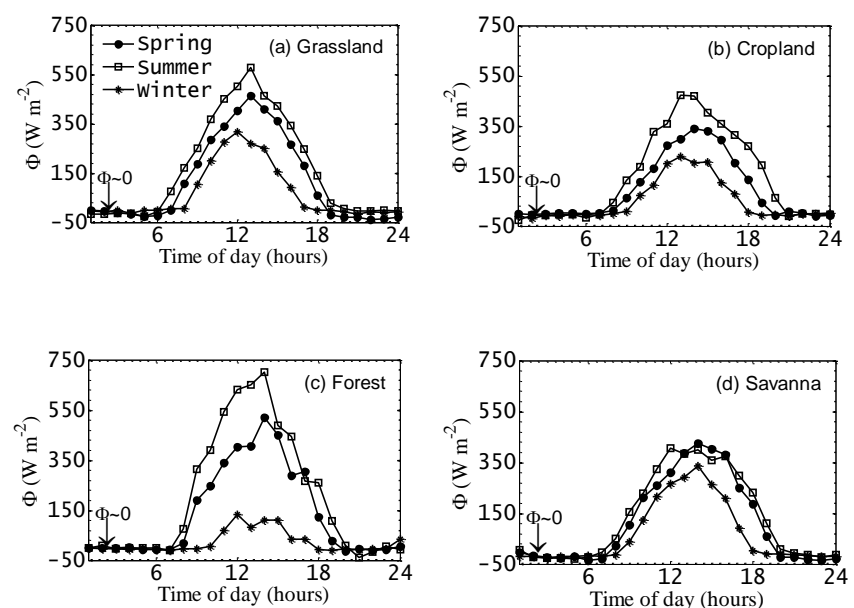

Figure 3. Examples of the diurnal evolution of net available energy $(\Phi)(=\lambda E+H)$ during three different times of year over four representative biome types. This shows $\Phi \cong 0$ around 01:30 LT.

mixed forest (MF), evergreen needleleaf forest (ENF), deciduous broadleaf forest (DBF), savanna (SAV), grassland (GRA) and cropland (CRO). A comprehensive list of the site characteristics are provided in Table 1. Each tower evaluation data set is comprised of the 13:30 LT time samples of $R_{\mathrm{N}}, H$ and $\lambda E$ which correspond to the satellite overpass. Again, the evaluation is based on pooling these data into weighted monthly average values. For the evaluation we have elected to compare all 12 months of data for 2003, as this year had the best overlap between the FLUXNET and AIRS databases. However before directly validating the satellite-retrieved $\Phi$, the proposed $\Phi$ retrieval method is first evaluated using high-temporal-frequency ground-based observations of $R_{\mathrm{N}}$ and $T_{\mathrm{S}}$ over some eddy covariance sites representing four broad biome categories (grassland, cropland, forest and savanna). Both $R_{\mathrm{N}}$ and $T_{\mathrm{S}}$ at 13:30 LT and 01:30 LT were extracted from half-hourly measurements, and $\Phi$ at 13:30 LT was determined using Eq. (10a, b). The retrieved midday $\Phi$ was validated against tower-observed latent and sensible heat fluxes.

\section{Results}

Table 2 shows the results from the sensitivity analysis. For $G$ we see the importance of the longwave specification and in particular $\varepsilon_{\mathrm{C}}$. The standard deviation of the estimate of $G$ from the ensemble is $18 \mathrm{~W} \mathrm{~m}^{-2}$, giving approximate $95 \%$ confidence detection limits of $\pm 36 \mathrm{~W} \mathrm{~m}^{-2}$ on the estimates. $R_{\mathrm{N}}$ is sensitive to all components of the radiation balance calculation as expected (Table 2). The standard deviation of the estimate of $R_{\mathrm{N}}$ from the ensemble is $40 \mathrm{~W} \mathrm{~m}^{-2}$, giving approximate $95 \%$ detection limits of $\pm 80 \mathrm{~W} \mathrm{~m}^{-2}$ on the estimates (Table 2). Not surprisingly, the sensitivity results for
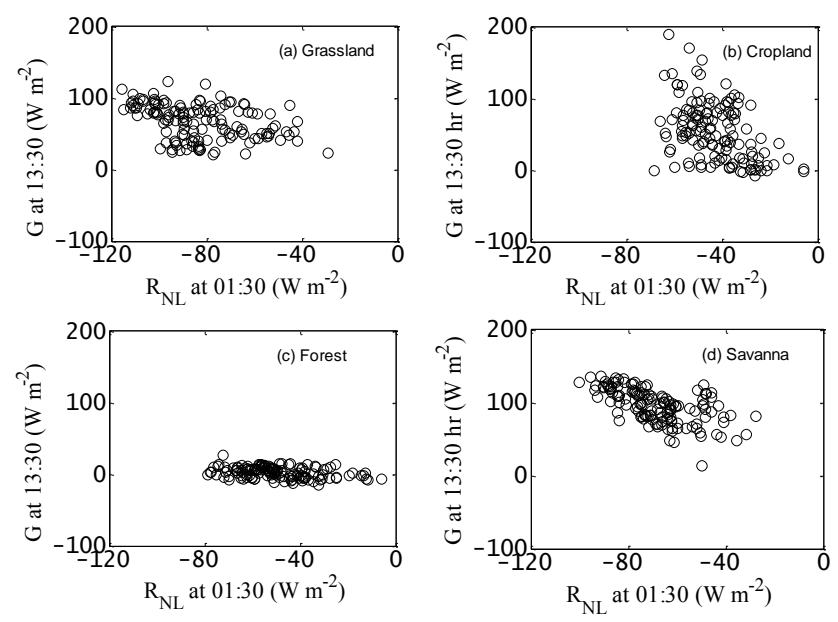

Figure 4. Observational relationship night-time (01:30LT) net longwave radiation $\left(R_{\mathrm{NL}}\right)$ and midday (13:30 LT) $G$ measurements. Despite the scale mismatch between the two measurements, moderate $(r=0.32-0.44)$ (forest, cropland) to high $(r=0.60)$ (grassland and savanna) relationship is notable.

$\Phi$ mirror those of $R_{\mathrm{N}}$, albeit with a marginally higher ensemble standard deviation of $44 \mathrm{~W} \mathrm{~m}^{-2}$ (Table 2).

The locations of the 30 terrestrial evaluation sites are marked in Fig. 1. Figure 5 shows annual average, global satellite scenes for 13:30LT $R_{\mathrm{N}}, c, G$ and $\Phi$ for the year 2003. Missing data in the images are mainly due to missing data in the AIRS soundings at high latitudes or over the mountain belts, where it is difficult to profile air temperature and relative humidity reliably. In addition, persistent cloudy conditions also prevent reliable retrieval and hence are rejected, although these will be less evident in the monthly or annual average data.

Figure 5a shows the global distribution of $R_{\mathrm{N}}$, which generally decreases with latitude, as expected. $R_{\mathrm{N}}$ also decreases over land due to the generally higher albedo, resulting in reduced absorption of the net shortwave radiation (Giambelluca et al., 1997; Gao and Wu, 2014) or relatively higher surface temperature increasing the net longwave component, especially over the drier regions (Liang et al., 1998; Trenberth, 2011). As a result the magnitude of $R_{\mathrm{N}}$ was around 200$300 \mathrm{~W} \mathrm{~m}^{-2}$ over the dry desert regions, whereas the oceanic values of $R_{\mathrm{N}}$ were $450-700 \mathrm{~W} \mathrm{~m}^{-2}$.

Figure $5 \mathrm{~b}$ shows the global distribution of $c$ (surface heat capacity). The oceanic values of 4 to $8 \mathrm{MJ} \mathrm{m}^{-2} \mathrm{~K}^{-1}$ are equivalent to 1 to $2 \mathrm{~m}$ of seawater, which appears reasonable on the daily time step to which they relate (Stramma et al., 1986; Schwartz, 2007). These oceanic values are somewhat noisy due to the small day-night temperature differences observed for the oceans giving a relatively poor signalto-noise ratio. However, behind this noise the pattern of oceanic $c$ appears relatively uniform as one might expect. Over land $c$ varies between 0.05 and $0.5 \mathrm{MJ} \mathrm{m}^{-2} \mathrm{~K}^{-1}$ with wetter tropical and high-latitude areas showing significantly 
Table 1. Eddy covariance sites used for the evaluation of the satellite-derived $R_{\mathrm{N}}$ and $\Phi$.

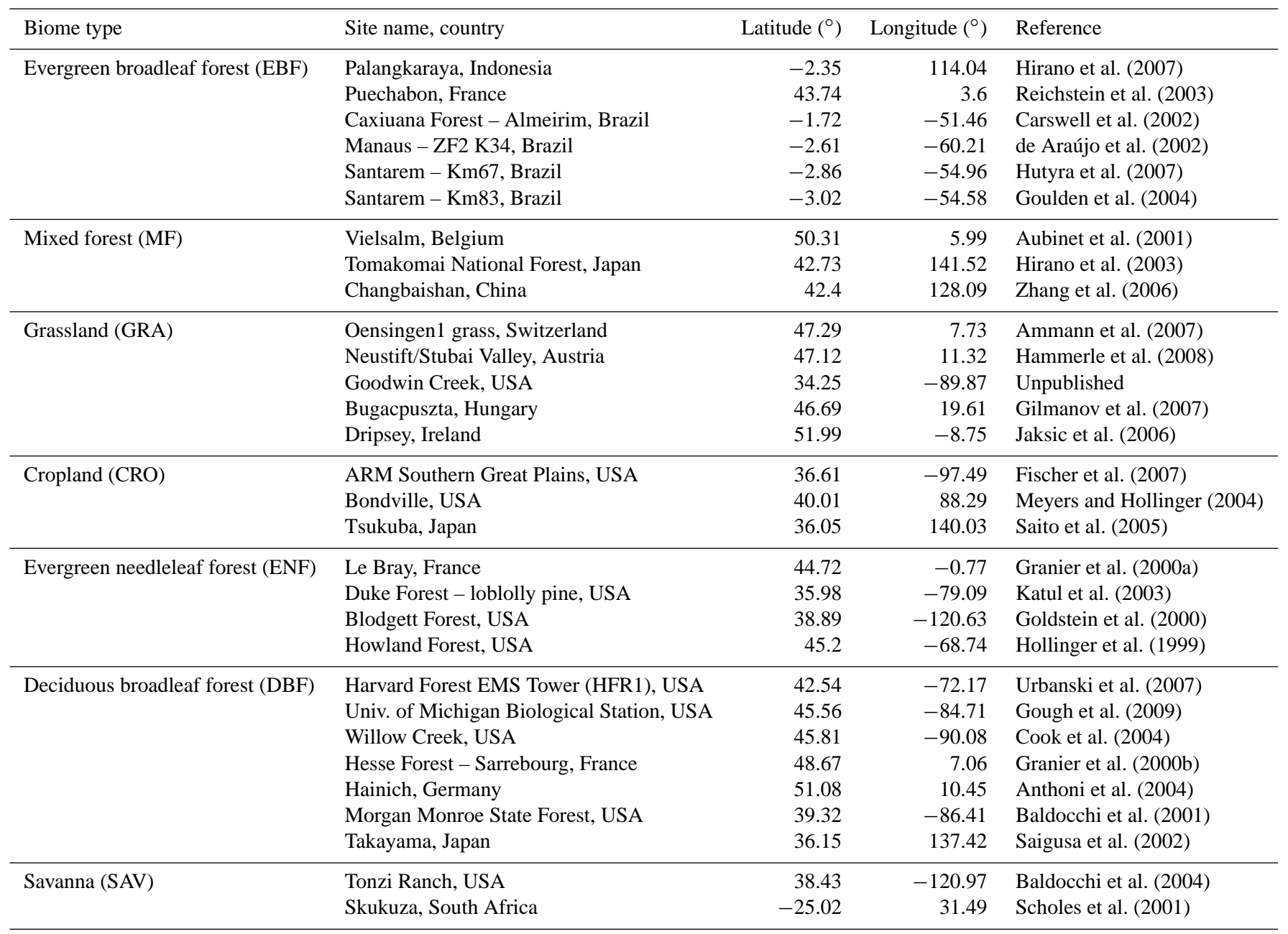

higher values than the drier, less vegetated areas, as expected. The soil equivalent depth of this heat capacity is approximately $0.01 \mathrm{~m}$, which again appears reasonable for a daily time step (Li and Islam, 1999), although in heavily vegetated areas $c$ is obviously comprised of a more complex aggregation.

Figure $5 \mathrm{c}$ shows the global distribution of $G$. These are the 13:30 LT values, hence their being net positive as an annual average. Between $20^{\circ}$ north and south, $G$ is approximately 10 to $20 \%$ of $R_{\mathrm{N}}$, and this rises to more than $40 \%$ above $50^{\circ}$ north and south (Hsieh et al., 2009). Given that this opposes the pattern of $R_{\mathrm{N}}$, one would conclude that there are either some deficiencies in the way $G$ is specified here or that $R_{\mathrm{N}}$ partitions into latent heat far more effectively than surface heating in these warm wet environments (Liu et al., 2005). Again, terrestrial values are lower than their oceanic equivalents, mainly due to the lower heat capacity as well as reduced $R_{\mathrm{N}}$ as discussed above. This also highlights the role of the vegetation layer in preventing ground heating (Baker and Baker, 2002; Bounoua et al., 2010). The Sahara appears particularly prominent in this scene, with high rates of midday heat accumulation, which appears to be associated with a combination of moderate net radiation and relatively high heat capacity. The heterogeneity in this region appears to be related to the pattern of bare darker rock.

Figure $5 d$ shows the global distribution of $\Phi$, which follows a similar pattern to $R_{\mathrm{N}}$ as expected, although the pattern of $G$ shown in Fig. 5c dictates that the north-south gradients in $\Phi$ are somewhat stronger than those of $R_{\mathrm{N}}$. Before discussing these results, we consider their evaluation. In the first step, we validated the new method of $\Phi$ retrieval at representative FLUXNET sites using ground observations of the surface radiation components $\left(T_{\mathrm{S}}, R_{\mathrm{N}}\right.$ and $\left.G\right)$ as input before directly evaluating the satellite-based retrievals. Tower-scale evaluation of daily midday (13:30 LT) $\Phi$ is illustrated in Fig. 6a, b, c and d for four broad biome categories, which shows a modest correlation $[r=0.91( \pm 0.03)$ 
Table 2. Sensitivity analysis results. The forcing data are taken for midsummer in the Southern Great Plains, USA. Sensitivities are locally linear, averaged across the ensemble response and expressed as dimensionless relative changes. Only absolute sensitivities $>0.1$ are shown. $N=10^{5}$ realisations.

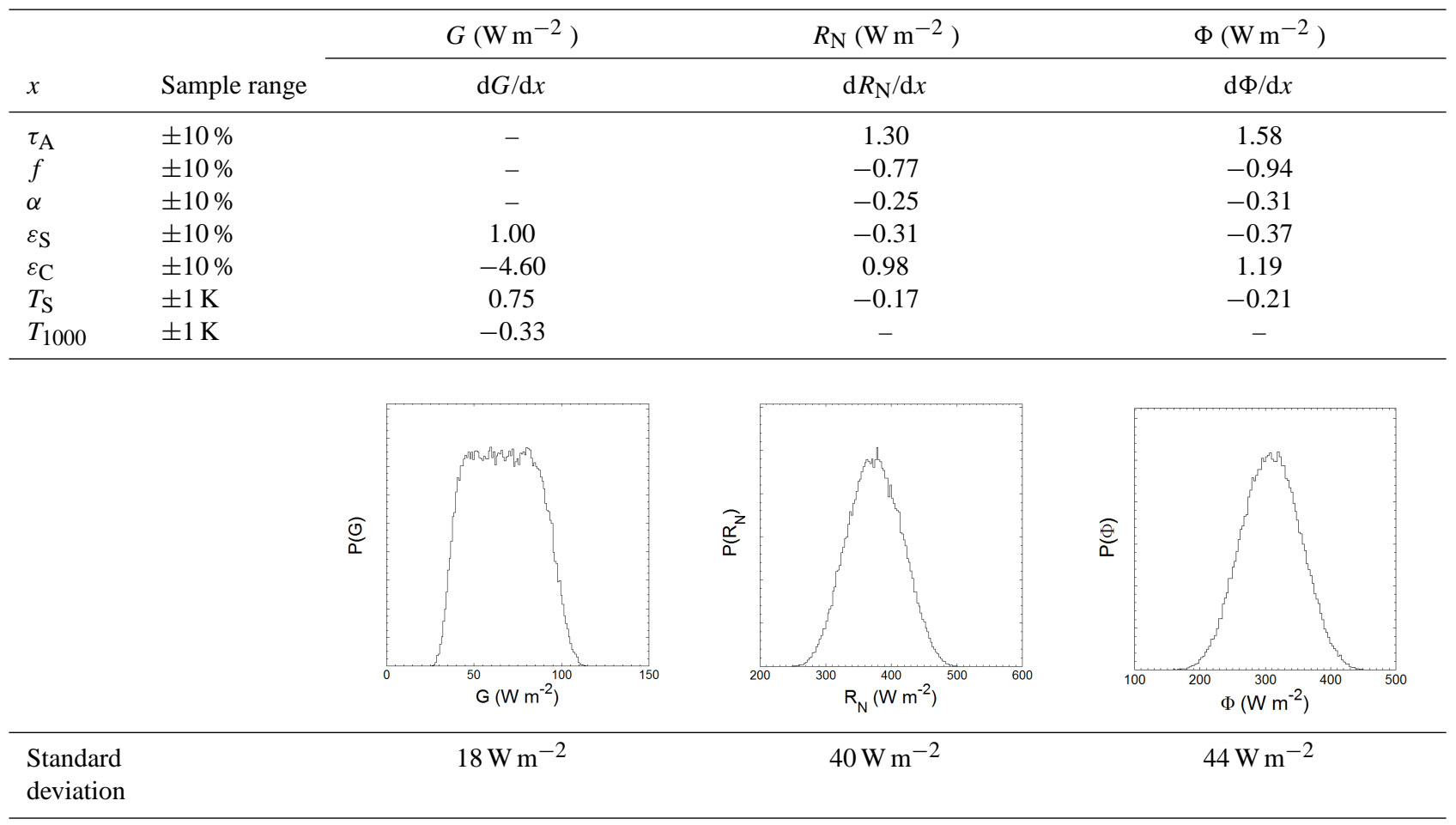

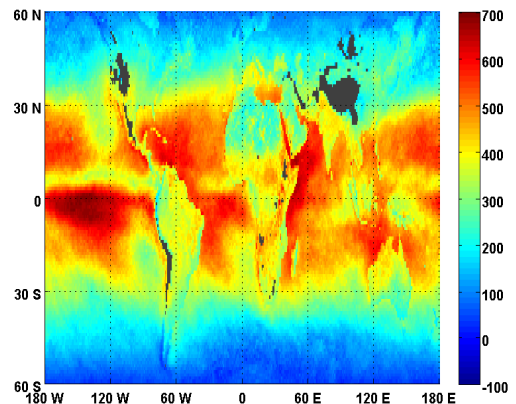

(a)

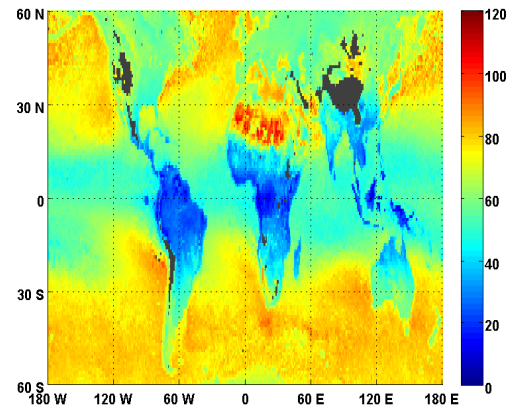

(c)

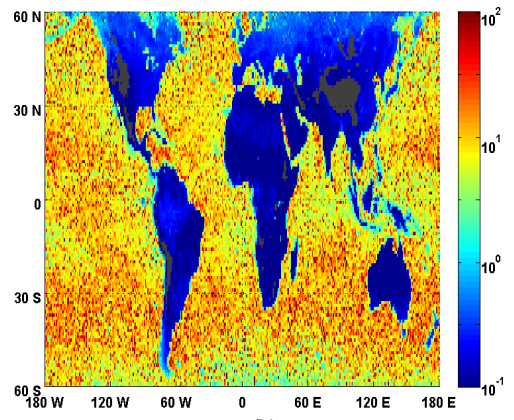

(b)

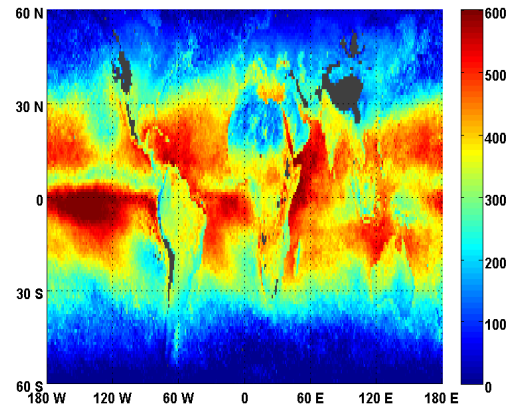

(d)

Figure 5. Global fields for annual average (year 2003) 13:30 LT: (a) net radiation, $R_{\mathrm{N}}\left(\mathrm{W} \mathrm{m}^{-2}\right)$; (b) surface heat capacity, $c\left(\mathrm{MJ} \mathrm{m}^{-2} \mathrm{~K}^{-1}\right.$ ); (c) surface heat accumulation rate, $G\left(\mathrm{~W} \mathrm{~m}^{-2}\right)$; (d) net available energy, $\Phi\left(\mathrm{W} \mathrm{m}^{-2}\right)$. 

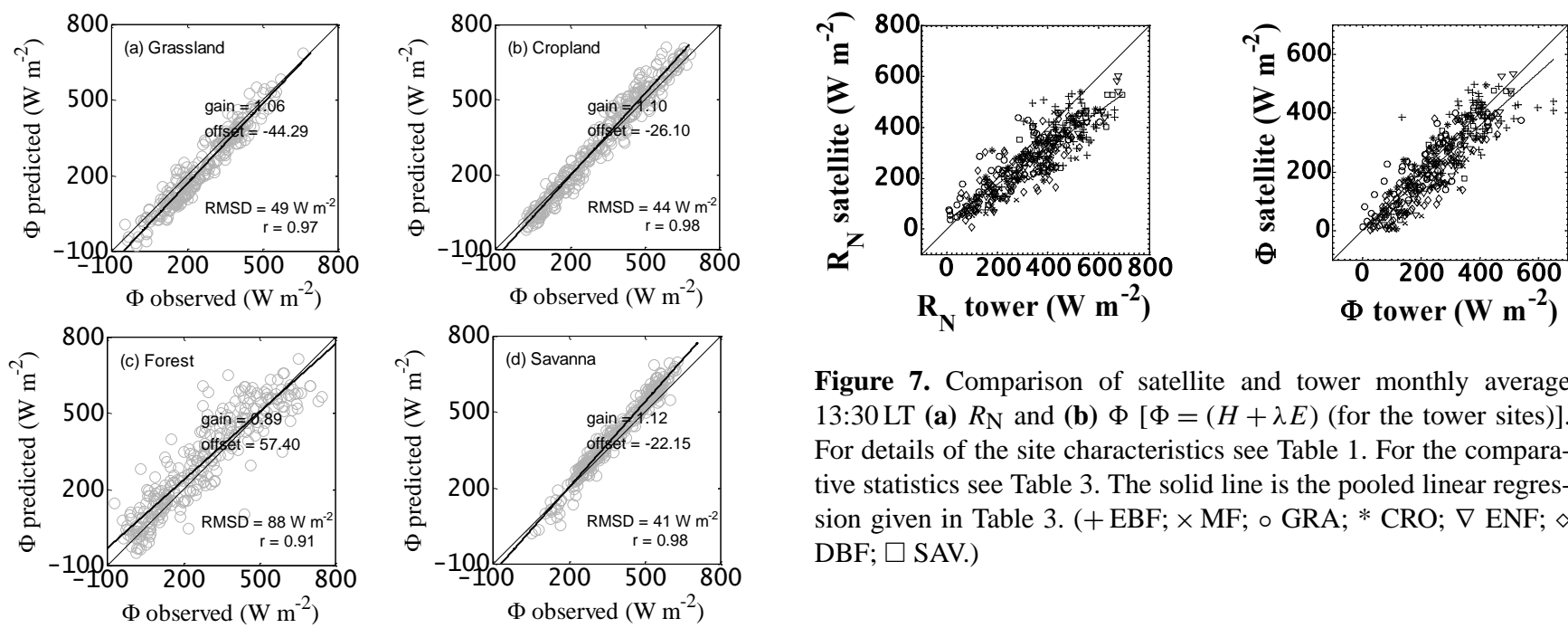

Figure 7. Comparison of satellite and tower monthly average 13:30 LT (a) $R_{\mathrm{N}}$ and (b) $\Phi[\Phi=(H+\lambda E)$ (for the tower sites)]. For details of the site characteristics see Table 1. For the comparative statistics see Table 3 . The solid line is the pooled linear regression given in Table 3. (+ EBF; $\times$ MF; 。 GRA; * CRO; $\nabla$ ENF; $\diamond$ DBF; $\square$ SAV.)

Figure 6. Validation of net available energy $(\Phi)(=\lambda E+H)$ using high-temporal-frequency (daily) observations of midday (13:30 LT) and night (01:30 LT) $R_{\mathrm{N}}$ and $T_{\mathrm{S}}$ (solving Eq. 10a and b) at the eddy covariance tower sites over four representative biomes.

to $0.98( \pm 0.04)]^{1}$ between observed and predicted $\Phi$ across all the biomes with regression statistics ranging between 0.89 $( \pm 0.07)$ and $1.12( \pm 0.05)$ for the gain and $-44.29( \pm 20.15)$ to 59.40 ( \pm 29.03 ) for the offset (Fig. 6). The root-meansquare deviation (RMSD) varied between 41 (savanna) and $88 \mathrm{~W} \mathrm{~m}^{-2}$ (forest).

Figure $7 \mathrm{a}$ shows the pooled evaluation of satellite $R_{\mathrm{N}}$, which produced an overall correlation of $r=0.88 \quad( \pm 0.03)$. Assuming both tower and satellite observations are linearly related through some "true" value, then the pooled values are co-related by $R_{\mathrm{N}}($ satellite $)=0.75( \pm 0.02) R_{\mathrm{N}}($ tower $)+23.37( \pm 8.20)$, i.e. a small but significant underestimation in $R_{\mathrm{N}}$ (satellite) relative to $R_{\mathrm{N}}$ (tower). The RMSD between the two was $98 \mathrm{~W} \mathrm{~m}^{-2}$. The biome-specific statistics for $R_{\mathrm{N}}$ are given in Table 3, which reveals correlations ranging between 0.65 (EBF) and 0.96 (ENF), RMSD ranging between 74 (GRA) and $127 \mathrm{~W} \mathrm{~m}^{-2}(\mathrm{EBF})$, and regression statistics ranging between $0.58( \pm 0.08)$ and $0.87( \pm 0.04)$ for the gain and $-32.40( \pm 23.73)$ and $107.45( \pm 39.93)$ for the offset.

Figure $7 \mathrm{~b}$ shows the evaluation for $\Phi$, which produced pooled statistics of $r=0.87( \pm 0.03)$ and an RMSD of $72 \mathrm{~W} \mathrm{~m}^{-2}$, and the regression between the satellitepredicted and tower-observed $\Phi$ produced a regression line of $\Phi($ satellite $)=0.90( \pm 0.03) \Phi($ tower $)-2.43( \pm 8.19)$. The biome-specific statistics for $\Phi$ are also given in Table 3 showing correlations ranging from 0.70 (EBF) to 0.95 (ENF), RMSD ranging between 62 (GRA \& SAV) and $88 \mathrm{~W} \mathrm{~m}^{-2}$ (EBF) and regression coefficients ranging between 0.66

\footnotetext{
${ }^{1}$ All uncertainties are expressed as \pm 1 standard deviation unless otherwise stated.
}

$( \pm 0.08)$ and $1.01( \pm 0.05)$ and between $-65.25( \pm 27.07)$ and $108.71( \pm 32.10)$ for the gain and offset, respectively.

Figure 8 shows a sample of monthly time series for $\Phi$ for both the satellite and the towers. The sites were selected to represent the biome classes considered here, as well as ones for which complete annual data sets for 2003 were available. These results show that the satellite estimates generally track the trends in the tower data and hence that the pooled statistics are not masking the within site variability. Again, the site-wise comparative statistics for these data are given in Table 3 .

\section{Discussion}

For $R_{\mathrm{N}}$ the statistics relating the satellite and tower data are different with to results of the following authors: Bisht et al. (2005), who obtained $74 \mathrm{~W} \mathrm{~m}^{-2}$ RMSD when evaluating MODIS Terra geophysical land products over the Southern Great Plains of the USA (our RMSD in grassland is only comparable here, while other biomes show larger error); Jacobs et al. (2004), who obtained a $14-46 \mathrm{~W} \mathrm{~m}^{-2}$ RMSD (12.2\% relative RMSD) when determining hourly $R_{\mathrm{N}}$ using GOES (Geostationary Operational Environmental Satellite) data over wetlands in southern Florida; Cai et al. (2007), who obtained $13.7 \%$ error when evaluating MODIS Terra-Aqua data over China; Bisht and Bras (2010), who obtained $39-51 \mathrm{~W} \mathrm{~m}^{-2}$ RMSD over the central USA using MODIS Terra atmospheric data at $5-10 \mathrm{~km}$ spatial resolution; and Hwang et al. (2013) and Hou et al. (2014), who reported RMSD in instantaneous and daily $R_{\mathrm{N}}$ to be 58 142 and $37-40 \mathrm{~W} \mathrm{~m}^{-2}$ over Southeast Asia and China, respectively, using MODIS Terra data products. Stackhouse et al. (2000) evaluated the International Satellite Cloud Climatology Project (ISCCP) data and found errors in the range of 10 to $15 \mathrm{~W} \mathrm{~m}^{-2}$ in monthly average shortwave and longwave radiative fluxes. Other studies reported $33-60 \mathrm{~W} \mathrm{~m}^{-2} \mathrm{RMSD}$ in daily $R_{\mathrm{N}}$ using $5 \mathrm{~km}$ MODIS Terra optical and thermal 
data (a comprehensive list of relevant studies is given in Table 4). It is important to emphasise that, in the present study, the RMSD is being impacted in two ways: due to spatial scale mismatch and due to the time integration. When these errors are compounded in the derivation of $R_{\mathrm{N}}$ and compared with tower data, an RMSD of the order of $98 \mathrm{~W} \mathrm{~m}^{-2}$ appears reasonable considering the coarse spatial resolution of the AIRS data $\left(1^{\circ} \times 1^{\circ}\right)$.

There have been very few attempts to retrieve satellite estimates of $\Phi$ and compare these with ground truth data, although the statistics from our attempt appear to be parallel to the results of Stisen et al. (2008), who studied a single grassland site in the Senegal River basin using moderate (high) spatio-temporal resolution $(5 \mathrm{~km}$ spatial resolution, 15 min temporal resolution) MSG (Meteosat Second Generation) geostationary satellite data and obtained a correlation of $r=0.71$ and an RMSD of $43 \mathrm{~W} \mathrm{~m}^{-2}$ in comparison to the surface measurements. While estimating evapotranspiration over Indian agroecosystems, Bhattacharya et al. (2010) obtained an RMSD of $56 \mathrm{~W} \mathrm{~m}^{-2}$ for noontime $\Phi$ using $8 \mathrm{~km}$ resolution Indian geostationary satellite data. In another study with MODIS Aqua data over semi-arid agroecosystems in India, Bhattacharya et al. (2011) reported an RMSD of $34 \mathrm{~W} \mathrm{~m}^{-2}$ in daily average $\Phi$, which was associated with a significant tendency to underestimate $\Phi$. As was common to all these studies, the ground heat flux was either modelled as an empirical approximation employing remotely sensed surface variables (albedo, vegetation index and $T_{\mathrm{S}}$ ) or as a fixed fraction of $R_{\mathrm{N}}$. Murray and Verhoef (2007) argued that these empirical approaches do not generalise well. In particular, prescribing $G$ as a fixed fraction of $R_{\mathrm{N}}$ overlooks the role played by the thermal inertia of the land surface (Santanello and Friedl, 2003), leading to an underestimation of $G$ in the morning and overestimation during the afternoon (Gentine et al., 2007). The retrieval of $G$ proposed here using day-night surface temperature information attempts to account for this thermal inertia effect, and the results appear to support this approach especially when considering the scale mismatch between the tower and satellite observations.

As seen in Fig. 7a, there is a systematic underestimation of $R_{\mathrm{N}}$ relative to the tower values which exceeds the typical accuracy of net radiometer measurements of $20 \mathrm{~W} \mathrm{~m}^{-2}$ quoted by Foken (2008). We examined this underestimation in more detail wherever possible by evaluating three of the individual radiation components of $R_{\mathrm{N}}\left(R_{\mathrm{S} \downarrow}, R_{\mathrm{L} \downarrow}\right.$ and $\left.R_{\mathrm{L} \uparrow}\right)$. All tower sites provided measurements of $R_{\mathrm{S} \downarrow}$ (but not $R_{\mathrm{S} \uparrow}$ ). Figure 9a shows $R_{\mathrm{S} \downarrow}$ is systematically underestimated at the satellite scale, with $R_{\mathrm{S} \downarrow}($ satellite $)=0.70( \pm 0.02) R_{\mathrm{S} \downarrow}($ tower $)+68( \pm 12.24)$, which accounts for the mismatch of $R_{\mathrm{N}}$ (satellite) $\approx$ $0.75 R_{\mathrm{N}}$ (tower). Before attempting to account for the various reasons for this underestimation, it is important to realise that, unlike the IR components, the shortwave components are all-sky retrievals, i.e. like the tower data they do not omit cloudy-sky conditions. As a result, any bias in the shortwave
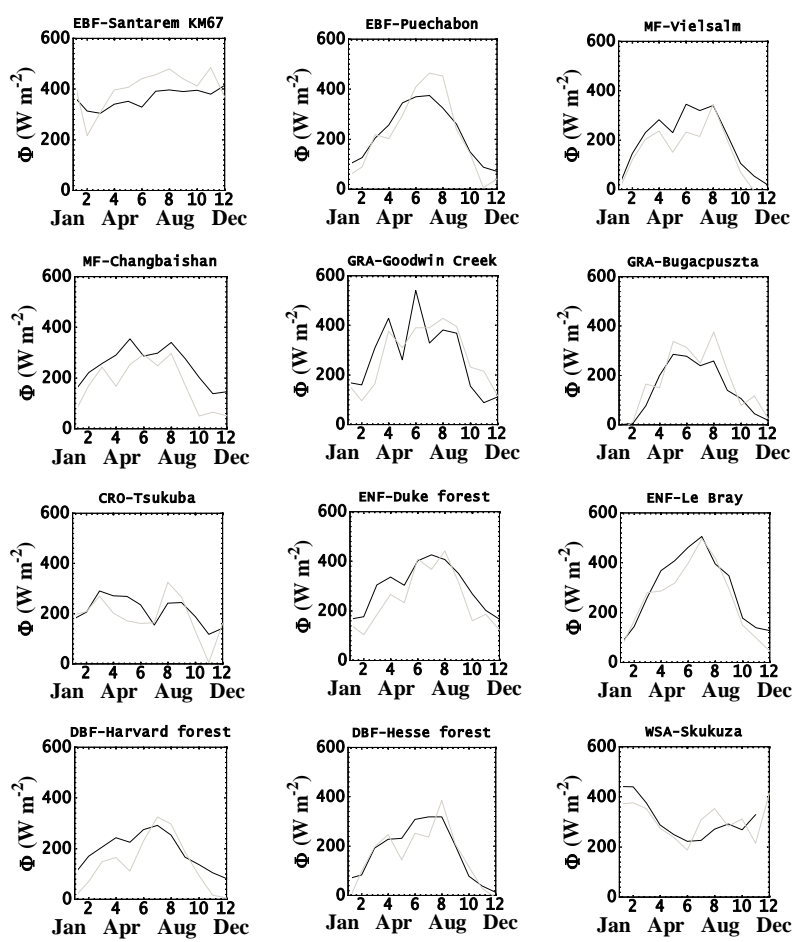

Figure 8. Satellite (grey) and tower (black) time series of monthly average 13:30 LT net available energy $\Phi[\Phi=(H+\lambda E)$ (for the tower sites)] for a selection of sites for 2003. The numbers on the $x$ axis are the month numbers, i.e. January is month number 1 and December is month number 12 .

is not as a result of biased sampling when comprising the monthly average. Furthermore, the omission of non-clear-sky data would tend to lead to $R_{\mathrm{S} \downarrow}$ (satellite) $>R_{\mathrm{S} \downarrow}$ (tower).

Clearly, the retrieval of atmospheric shortwave transmissivity $\left(\tau_{\mathrm{A}}\right)$ using cloud cover fraction is the principal reason for $R_{\mathrm{S} \downarrow}$ (satellite) $<R_{\mathrm{S} \downarrow}$ (tower) (Fig. 9a). The sensitivity analysis presented in Table 2 also indicates the significant sensitivity of $R_{\mathrm{N}}$ and $\Phi$ to the cloud cover fraction and atmospheric transmissivity. This shows that the method presented in the manuscript to estimate $R_{\mathrm{S} \downarrow}$ needs further improvements. If we assume $\tau_{\mathrm{A}}$ to be the principal reason for $R_{\mathrm{S} \downarrow}$ (satellite) $<R_{\mathrm{S} \downarrow}$ (tower), then a global value of 0.75 would be, on average, too low (Gueymard, 2003). A recent study of Longman et al. (2012) for the Mauna Loa Observatory (MLO) demonstrated the clear-sky $\tau_{\mathrm{A}}$ could go up to 0.90 . Given the relatively well defined relationship between $R_{\mathrm{S} \downarrow}$ (satellite) and $R_{\mathrm{S} \downarrow}$ (tower) seen in Fig. 3c, one would imagine that a more sophisticated dynamic representation of $\tau_{\mathrm{A}}$ would offer substantial improvements in $R_{\mathrm{S} \downarrow}$ (satellite). Retrieval of $\tau_{\mathrm{A}}$ including other atmospheric (e.g. cloud optical depth, aerosol optical depth, total precipitable water etc.) and surface (for example, single scattering albedo) variables in addition to the cloud cover fraction would offer a potential possibility of refining the $R_{\mathrm{S} \downarrow}$ estimates (Chen et al., 2014; Longman et al., 2012; Kim and 
Table 3. Comparative statistics for the satellite- and tower-derived monthly midday (13:30LT) $R_{\mathrm{N}}$ and $\Phi$ for a range of biomes. Values in parenthesis are \pm 1 standard deviation.

\begin{tabular}{|c|c|c|c|c|c|c|c|c|c|c|}
\hline \multirow[b]{2}{*}{ Biome } & \multicolumn{5}{|c|}{$R_{\mathrm{N}}$} & \multicolumn{5}{|c|}{$\Phi$} \\
\hline & $\begin{array}{r}\text { RMSD } \\
\left(\mathrm{W} \mathrm{m}^{-2}\right)\end{array}$ & Gain & Offset & $r$ & $N$ & $\begin{array}{r}\text { RMSD } \\
\left(\mathrm{W} \mathrm{m}^{-2}\right)\end{array}$ & Gain & Offset & $r$ & $N$ \\
\hline EBF & 126.67 & $\begin{array}{r}0.58 \\
( \pm 0.08)\end{array}$ & $\begin{array}{r}107.45 \\
( \pm 39.93)\end{array}$ & $\begin{array}{r}0.65 \\
( \pm 0.09)\end{array}$ & 69 & 87.67 & $\begin{array}{r}0.66 \\
( \pm 0.08)\end{array}$ & $\begin{array}{r}108.71 \\
( \pm 32.10)\end{array}$ & $\begin{array}{r}0.70 \\
( \pm 0.09)\end{array}$ & 65 \\
\hline MF & 104.21 & $\begin{array}{r}0.82 \\
( \pm 0.07)\end{array}$ & $\begin{array}{r}-32.40 \\
( \pm 23.73)\end{array}$ & $\begin{array}{r}0.89 \\
( \pm 0.08)\end{array}$ & 36 & 87.29 & $\begin{array}{r}0.97 \\
( \pm 0.10)\end{array}$ & $\begin{array}{r}-65.25 \\
( \pm 27.07)\end{array}$ & $\begin{array}{r}0.86 \\
( \pm 0.09)\end{array}$ & 32 \\
\hline GRA & 74.29 & $\begin{array}{r}0.73 \\
( \pm 0.05)\end{array}$ & $\begin{array}{r}51.37 \\
( \pm 15.88)\end{array}$ & $\begin{array}{r}0.88 \\
( \pm 0.06)\end{array}$ & 59 & 61.51 & $\begin{array}{r}0.83 \\
( \pm 0.07)\end{array}$ & $\begin{array}{r}15.71 \\
( \pm 16.21)\end{array}$ & $\begin{array}{r}0.86 \\
( \pm 0.07)\end{array}$ & 53 \\
\hline CRO & 89.13 & $\begin{array}{r}0.73 \\
( \pm 0.08)\end{array}$ & $\begin{array}{r}35.62 \\
( \pm 28.57)\end{array}$ & $\begin{array}{r}0.84 \\
( \pm 0.09)\end{array}$ & 36 & 53.31 & $\begin{array}{r}0.99 \\
( \pm 0.10)\end{array}$ & $\begin{array}{r}-0.23 \\
( \pm 23.98)\end{array}$ & $\begin{array}{r}0.87 \\
( \pm 0.09)\end{array}$ & 36 \\
\hline ENF & 85.45 & $\begin{array}{r}0.87 \\
( \pm 0.04)\end{array}$ & $\begin{array}{r}-26.83 \\
( \pm 14.78)\end{array}$ & $\begin{array}{r}0.96 \\
( \pm 0.04)\end{array}$ & 48 & 66.7 & $\begin{array}{r}1.01 \\
( \pm 0.05)\end{array}$ & $\begin{array}{r}-56.56 \\
( \pm 15.27)\end{array}$ & $\begin{array}{r}0.95 \\
( \pm 0.05)\end{array}$ & 46 \\
\hline DBF & 92.77 & $\begin{array}{r}0.71 \\
( \pm 0.05)\end{array}$ & $\begin{array}{r}21.74 \\
( \pm 15.15)\end{array}$ & $\begin{array}{r}0.85 \\
( \pm 0.06)\end{array}$ & 84 & 71.57 & $\begin{array}{r}0.88 \\
( \pm 0.06)\end{array}$ & $\begin{array}{r}-16.70 \\
( \pm 14.23)\end{array}$ & $\begin{array}{r}0.85 \\
( \pm 0.06)\end{array}$ & 80 \\
\hline SAV & 103.98 & $\begin{array}{r}0.69 \\
( \pm 0.08)\end{array}$ & $\begin{array}{r}56.28 \\
( \pm 36.08)\end{array}$ & $\begin{array}{r}0.87 \\
( \pm 0.11)\end{array}$ & 23 & 61.98 & $\begin{array}{r}0.97 \\
( \pm 0.11)\end{array}$ & $\begin{array}{r}-14.42 \\
( \pm 37.68)\end{array}$ & $\begin{array}{r}0.88 \\
( \pm 0.25)\end{array}$ & 32 \\
\hline Pooled & $\begin{array}{r}98.21 \\
(28 \%)\end{array}$ & $\begin{array}{r}0.75 \\
( \pm 0.02)\end{array}$ & $\begin{array}{r}23.37 \\
( \pm 8.20)\end{array}$ & $\begin{array}{r}0.88 \\
( \pm 0.03)\end{array}$ & 355 & $\begin{array}{r}72.26 \\
(22 \%)\end{array}$ & $\begin{array}{r}0.90 \\
( \pm 0.03)\end{array}$ & $\begin{array}{r}-2.43 \\
( \pm 8.19)\end{array}$ & $\begin{array}{r}0.87 \\
( \pm 0.03)\end{array}$ & 335 \\
\hline
\end{tabular}

$N$ : number of data points falling under individual biomes. $\Phi=(H+\lambda E)$ (for the tower sites).

EBF: evergreen broadleaf forest; MF: mixed forest; GRA: grassland; CRO: cropland; ENF: evergreen needleleaf forest; DBF: deciduous broadleaf forest; SAV: savanna.

Table 4. Summary of errors and characteristics of some of the dedicated satellite-based $R_{\mathrm{N}}$ and $R_{\mathrm{S} \downarrow}$ retrieval studies.

\begin{tabular}{|c|c|c|c|c|c|}
\hline $\begin{array}{l}\text { Radiative flux } \\
\text { variables }\end{array}$ & Reference & Sensor used & $\begin{array}{l}\text { Spatial } \\
\text { resolution }\end{array}$ & $\begin{array}{l}\text { Temporal } \\
\text { resolution }\end{array}$ & $\begin{array}{l}\text { RMSD } \\
\left(\mathrm{W} \mathrm{m}^{-2}\right)\end{array}$ \\
\hline \multirow[t]{10}{*}{$R_{\mathrm{N}}$} & Verstraeten et al. (2005) & NOAA AVHRR & $1 \mathrm{~km}$ & Instantaneous & $5-5$ \\
\hline & Bisht et al. (2005) & MODIS Terra & $5 \mathrm{~km}$ & Instantaneous & 74 \\
\hline & Cai et al. (2007) & MODIS Terra and Aqua synergy & $5 \mathrm{~km}$ & Instantaneous & 19 \\
\hline & Bisht and Bras (2010) & MODIS Terra & $5 \mathrm{~km}$ & Instantaneous & $23-39$ \\
\hline & Hwang et al. (2013) & MODIS Terra & $5 \mathrm{~km}$ & Instantaneous & $58-142$ \\
\hline & Hou et al. (2014) & MODIS Terra & $5 \mathrm{~km}$ & Daily & $37-40$ \\
\hline & Bisht et al. (2005) & MODIS Terra & $5 \mathrm{~km}$ & Daily & 60 \\
\hline & Peng et al. (2013) & MODIS Terra & $5 \mathrm{~km}$ & Daily & 33 \\
\hline & Jin et al. (2011) & MODIS Terra & $5 \mathrm{~km}$ & Monthly average & 44 \\
\hline & $\begin{array}{l}\text { Mallick et al. (2014) } \\
\text { (current study) }\end{array}$ & AIRS and MODIS Terra & $1^{\circ}$ & $\begin{array}{l}\text { Instantaneous } \\
\text { monthly average }\end{array}$ & $74-126$ \\
\hline \multirow[t]{8}{*}{$R_{\mathrm{S} \downarrow}$} & Chen et al. (2014) & MODIS Terra & $1^{\circ}$ & Daily & 39 \\
\hline & Sun et al. (2013) & In situ observations & Tower footprint & Instantaneous & $36-89$ \\
\hline & Huang et al. (2012) & MODIS Terra & $5 \mathrm{~km}$ & Instantaneous & $\begin{array}{l}54-83 \\
\text { (in } R_{\mathrm{NS}} \text { ) }\end{array}$ \\
\hline & Huang et al. (2011) & MODIS Terra & $5 \mathrm{~km}$ & Instantaneous & $60-137$ \\
\hline & Wang and Pinker (2009) & MODIS Terra and Aqua & $1^{\circ}$ & Instantaneous & $77-158$ \\
\hline & Kim and Hogue (2008) & MODIS Terra & $5 \mathrm{~km}$ & Instantaneous & 76 \\
\hline & Tang et al. (2006) & MODIS Terra & $5 \mathrm{~km}$ & Daily & $\begin{array}{l}20-35 \\
\text { (in } R_{\mathrm{NS}} \text { ) }\end{array}$ \\
\hline & $\begin{array}{l}\text { Mallick et al. (2014) } \\
\text { (current study) }\end{array}$ & AIRS & $1^{\circ}$ & $\begin{array}{l}\text { Instantaneous } \\
\text { monthly average }\end{array}$ & 110 \\
\hline
\end{tabular}




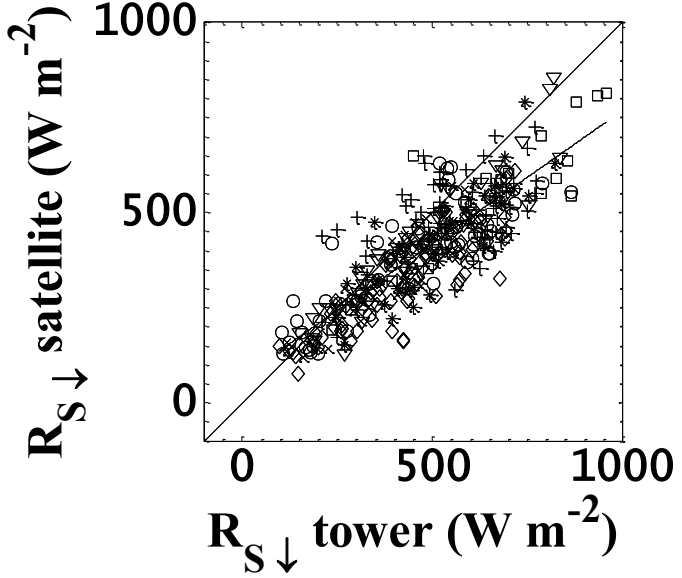

(a)

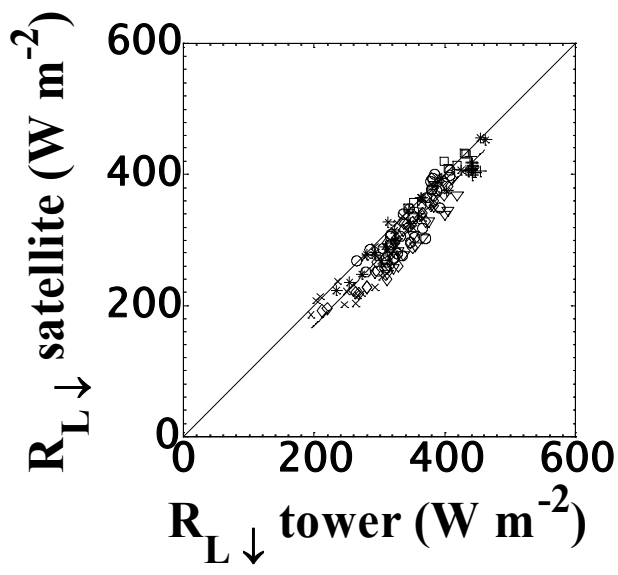

(b)

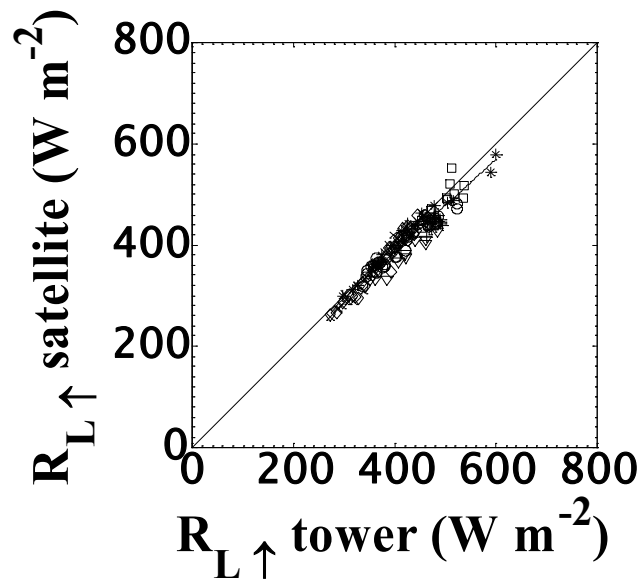

(c)

Figure 9. Comparison of satellite and tower monthly average 13:30 LT (a) $R_{\mathrm{S} \downarrow}$, (b) $R_{\mathrm{L} \downarrow}$ and (c) $R_{\mathrm{L} \uparrow}$ for a selection of sites for which tower data for $R_{\mathrm{S} \downarrow}$ (360 data points), $R_{\mathrm{L} \downarrow}$ (159 data points) and $R_{\mathrm{L} \uparrow}$ (159 data points) were available. The linear fit (solid line) between the two sources of $R_{\mathrm{S} \downarrow}$ is $R_{\mathrm{S} \downarrow}(\mathrm{AIRS})=0.70( \pm 0.02) R_{\mathrm{S} \downarrow}$ (tower) $+67.68( \pm 12.24) ; r=0.84( \pm 0.03)$. The linear fit (solid line) between the two sources of $R_{\mathrm{L} \downarrow}$ is $R_{\mathrm{L} \downarrow}$ (AIRS) $=1.03( \pm 0.03) R_{\mathrm{L} \downarrow}$ (tower) 36.91 ( \pm 10.05$) ; r=0.95$ ( \pm 0.03 ). The linear fit (solid line) between the two sources of $R_{\mathrm{L} \uparrow}$ is $R_{\mathrm{L} \uparrow}(\mathrm{AIRS})=0.91( \pm 0.02) R_{\mathrm{L} \uparrow}($ tower $)+20.43( \pm 8.77) ; r=0.96( \pm 0.02)$. The dashed lines are $1: 1$ in all cases. $(+\mathrm{EBF} ; \times \mathrm{MF} ; \circ$ GRA; * $\mathrm{CRO} ; \nabla \mathrm{ENF} ; \diamond \mathrm{DBF} ; \square \mathrm{SAV}$.)

Hogue, 2008). The exo-atmospheric shortwave radiation frequently interacts with the clouds, aerosols and water vapour during the transmission towards the Earth's surface. This interaction is wavelength-dependent over the entire shortwave spectrum (Chen et al., 2014; Kim and Hogue, 2008; Gueymard, 2003), and therefore a spectrally resolved $\tau_{\mathrm{A}}$ scheme will be valuable to accurately determine $R_{\mathrm{S} \downarrow}$. Recalibration of $\tau_{\mathrm{A}}$ using the tower data is also a possibility, although we have avoided this given that the AIRS cloud cover fraction and scale mismatch between the satellite and tower could also be involved in the observed bias. For example, the diffuse fraction of $R_{\mathrm{S} \downarrow}$ (tower) can become enriched by surfacereflected solar radiation, particularly in undulating terrain (Dubayah and Loechel, 1997; Sultan et al., 2014). Nonlin- ear scaling effects of surface albedo (Oliphant et al., 2003; Salomon et al., 2006) can also be included in this because surface albedo interacts nonlinearly with surface characteristics such as surface wetness and land surface temperature (Ryu et al., 2008) or the leaf area index (Hammerle et al., 2008). Although, the RMSD of instantaneous $R_{\mathrm{S} \downarrow}$ obtained in the present study $\left(110 \mathrm{~W} \mathrm{~m}^{-2}\right)$ is different to other studies where $R_{\mathrm{S} \downarrow}$ retrieval was based on either using parametric (radiative transfer) models or look-up tables derived from high-spatial-resolution MODIS data, it is worth comparing it with the statistics of some of those studies. Table 4 summarises the characteristics and associated errors of some of the recent $R_{\mathrm{S} \downarrow}$ estimation studies, and shows an RMSD of $36-89 \mathrm{~W} \mathrm{~m}^{-2}$ at flux tower footprint, $54-137 \mathrm{~W} \mathrm{~m}^{-2}$ at $5 \mathrm{~km}$ 
Table 5. The mean and standard deviation of monthly midday (13:30 LT) surface energy balance closure $\left(C_{\mathrm{EB}}\right)$ of different biome types for the 21 (out of 30) FLUXNET sites $(N)$ under study. Nine out of 30 sites had missing ground heat flux. $C_{\mathrm{EB}}$ is computed according to Stoy et al. (2013).

\begin{tabular}{lcc}
\hline Biome types & $N$ & $C_{\text {EB }}$ \\
\hline EBF & 2 & $0.92 \pm 0.15$ \\
MF & 3 & $0.76 \pm 0.12$ \\
GRA & 4 & $0.84 \pm 0.08$ \\
CRO & 3 & $0.77 \pm 0.10$ \\
ENF & 3 & $0.80 \pm 0.02$ \\
DBF & 4 & $0.66 \pm 0.05$ \\
SAV & 2 & $0.79 \pm 0.08$ \\
\hline
\end{tabular}

spatial resolution and $77-158 \mathrm{~W} \mathrm{~m}^{-2}$ at $1^{\circ}$ spatial resolution for the instantaneous $R_{\mathrm{S} \downarrow}$ estimates and $20-39 \mathrm{~W} \mathrm{~m}^{-2}$ for the daily $R_{\mathrm{S} \downarrow}$ (and net shortwave, $R_{\mathrm{NS}}$ ) estimates. Considering the simplicity of the current approach and the large spatial scale of the AIRS data, an RMSD of the order of $110 \mathrm{~W} \mathrm{~m}^{-2}$ appears reasonable.

To probe the specification of $R_{\mathrm{N}}$ further, we investigated the individual longwave radiation components in relation to measures of theses fluxes available for a limited subset (14) of tower sites where the longwave radiative flux components were directly measured by pyrgeometers. From Fig. $9 \mathrm{~b}$ and c it appears that there is quite good agreement between the satellite and tower data for both $R_{\mathrm{L} \downarrow}$ and $R_{\mathrm{L} \uparrow}$ and that any mismatch is insufficient to explain the discrepancy in $R_{\mathrm{N}}$. This is somewhat surprising for two reasons. Firstly, unlike the shortwave component, $R_{\mathrm{L}}$ (tower) is all-sky whilst $R_{\mathrm{L}}$ (satellite) is only from clear-sky conditions where IR retrieval is possible. As a result, one would anticipate very significant differences in the monthly average values of the longwave components. However, it is difficult to predict the effect of this biased sampling on $R_{\mathrm{NL}}$ (satellite) given that cloud interacts with both $R_{\mathrm{L} \downarrow}$ and $R_{\mathrm{L} \uparrow}$ in complex ways. Secondly, one would anticipate significant scaling effects from the $T^{4}$ nonlinearity in Eq. (6), which can result in a disproportionate contribution of warmer elements within the system to both $R_{\mathrm{L} \downarrow}$ and $R_{\mathrm{L} \uparrow}$ (Kustas and Norman, 2000; Lakshmi and Zehrfuhs, 2002, Corbari et al., 2010). The fact that these effects are not seen to any significant degree could point to compensating errors in the analysis but does not distract from the central message of the importance of the bias in the shortwave when accounting for $R_{\mathrm{N}}$ (satellite) $<R_{\mathrm{N}}$ (tower).

Figure $7 \mathrm{~b}$ and Table 3 show that $\Phi$ (satellite) $\approx 0.90 \Phi$ (tower), suggesting a slight compensation for the underspecification of $R_{\mathrm{S} \downarrow}$ through the underspecification of $G$ from the satellite data. However, this evaluation assumes the energy balance to be closed in the tower data (i.e. $R_{\mathrm{N}}-G=\lambda E+H$ ), which typically is not the case, with $\lambda E+H$ often falling short of $R_{\mathrm{N}}-G$ by $20 \%$ (Wilson et al., 2002). Because the causes of this energy imbalance remain controversial (see Foken, 2008, for a review), it is difficult to estimate how much the tower values of $\lambda E+H$ are actually biased and hence the extent to which this bias affects our evaluation. Stoy et al. (2013) recently found a systematic relationship of the surface energy balance closure with landscape heterogeneity over 173 FLUXNET tower sites and reported an energy imbalance of 9-30\% over diverse biomes. In another study, Amiro et al. (2009) found relatively better fulfilment of energy balance closure by averaging data over longer periods. The monthly averages of (AIRS overpass time) 13:30 LT surface energy balance closure of the 30 sites used here (Table 5) show an average energy imbalance of $\sim 20 \%$ (ranging from 8 to $34 \%$ ). The errors in the tower data are also believed to be associated with different footprint characteristics for the different instruments used (Lin et al., 2008). For example, $R_{\mathrm{N}}$ observations typically have a footprint size of $\sim 10 \mathrm{~m}^{2}$, whilst air properties (e.g. air temperature, humidity) have footprint sizes of $>1 \mathrm{~km}^{2}$. By way of illustration, if, in the worst case, the entire energy imbalance were to be attributed exclusively to $\lambda E+H$ (i.e. $R_{\mathrm{N}}-G$ are quantified correctly), then the true midday $\lambda E+H$ could be some $20 \%$ greater (Wilson et al., 2002). As a result, the present bias seen in Table 3 would change to $\Phi$ (satellite) $\approx 0.72 \Phi$ (tower), again suggesting $R_{\mathrm{S} \downarrow}$ to be the main source of bias in the satellite retrievals for both $R_{\mathrm{N}}$ and $\Phi$.

We have only evaluated the satellite retrievals using data from terrestrial sites, and clearly it would be worthwhile repeating this for the ocean retrievals if possible. We have held back on this evaluation here because of the lack of an extensive network of instantaneous latent and sensible heat flux or radiative flux data over the oceans, although we note that the SEAFLUX project within the Global Energy and Water Experiment (GEWEX) initiative should give rise to such a database in the near future. From the terrestrial evaluation we would argue that the methodology employed here shows promise for specifying both noontime $R_{\mathrm{N}}$ and $\Phi$, although the results suggest the need for improvements, particularly in the specification of $R_{\mathrm{S} \downarrow}$. More detailed studies evaluating the representativeness of each tower site footprint in relation to the $1^{\circ}$ scale within which it is situated could prove useful in this regard as would methods for cloud-proofing the satellite retrievals under persistent cloudy-sky conditions. Similarly, evaluation under extreme conditions (e.g. high altitudes and latitudes) is also required.

\section{Conclusions}

We have demonstrated a novel retrieval for midday (13:30 LT) surface net available energy $(\Phi)$ by blending the monthly atmospheric and land surface variables of AIRS and MODIS sensors. We have attempted to structure the method such that the $\Phi$ retrieval does not depend on any offline calibration. We performed a two-step evaluation of the retrieved 
values for $\Phi$ at some representative surface radiation measurement sites and also over 30 FLUXNET sites from all over the globe.

Current $\Phi$ estimates performed well when compared against high spatio-temporal in situ measurements and coarse-spatial-resolution satellite retrievals. Consistent underestimation of $R_{\mathrm{N}}$ was noted due to the underestimation of shortwave radiation, and in tropical latitudes the $R_{\mathrm{N}}$ (and $\Phi)$ agreement was relatively weaker. Combination of highfrequency cloud dynamics and relatively low seasonal variability of $R_{\mathrm{S} \downarrow}$ makes it difficult to accurately model both $\Phi$ and $R_{\mathrm{N}}$. One of the key challenges in modelling $R_{\mathrm{N}}$ (and $\Phi)$ in the tropics is to account for fast-changing cloud cover fraction and cloud optical properties throughout the day.

With the availability of high-spatial-resolution $(1-5 \mathrm{~km})$ MODIS day-night optical and thermal data, our present approach could be extended to derive high-spatial-resolution $\Phi$ estimates at the global scale. This could be achieved by estimating MODIS-based day-night $R_{\mathrm{N}}$ and combining day-night $R_{\mathrm{N}}$ with day-night $T_{\mathrm{S}}$ observations. At the same time, the current methodology could also be used on hightemporal-frequency observations of geostationary satellites (e.g. GOES and METEOSAT). Once surface heat uptake and heat capacity (through Eq. 10) has been estimated, hourly $G$ and $\Phi$ could be determined from hourly $R_{\mathrm{N}}$ and $T_{\mathrm{S}}$ observations of geostationary satellites by assuming conservation of heat capacity over a particular day. Operational generation of satellite-based $\Phi$ product would be a valuable resource for a variety of investigations, such as estimating latent and sensible heat, evaluation of Earth system model outputs and quantifying the land-atmosphere coupling strength. Given that we have resorted to the minimal amount of calibration in deriving $\Phi$, it would appear sensible to adopt a similar philosophy in developing satellite-based schemes for latent and sensible heat fluxes as proposed in M2.

In addition to opportunities to specify large-scale surface heat and water vapour fluxes, the heat capacity estimates made here clearly carry information on variations in terrestrial properties such as surface moisture storage, and we envisage that studies to develop this concept further could prove fruitful, particularly because of the emergence of satellite microwave data against which the results could be compared.

Acknowledgements. We would like to acknowledge the Goddard Earth Sciences Data and Information Services Center (GES DISC) and staff involved with Level 1 and Atmosphere Archive and Distribution System (LAADS), NASA, for making the AIRS and MODIS data available. We kindly acknowledge all the site PIs who provided terrestrial flux data through the FLUXNET data archive. The AmeriFlux regional network component of this archive is supported with funding from the US Department of Energy through its Terrestrial Carbon project. K. Mallick would like to thank Loise Wandera for helping with map preparation. The authors declare no conflict of interests. This work was originally developed under
NERC grant number NEE0191531.

Edited by: P. Stoy

\section{References}

Adhikari, L., Wang, Z., and Whiteman, D.: Cloudy Assessment within an Atmospheric Infrared Sounder Pixel by Combining Moderate Resolution Spectroradiometer and Atmospheric Radiation Measurement Program Ground-Based Lidar and Radar Measurements, Sixteenth ARM Science Team Meeting Proceedings, Albuquerque, NM, March 27-31, 2006.

Amiro, B. D.: Measuring boreal forest evapotranspiration using the energy balance residual, J. Hydrol., 366, 112-118, 2009.

Ammann, C., Flechard, C. R., Leifeld, J., Neftel, A., and Fuhrer, J.: The carbon budget of newly established temperature grassland depends on management intensity, Agric. Ecosys. Environ., 121, 5-20, 2007.

Anderson, M. C., Allen, R. G., Morse, A., and Kustas, W. P.: Use of Landsat thermal imagery in monitoring evapotranspiration and managing water resources, Remote Sens. Environ., 122, 50-65, 2012.

Anthoni, P. M., Knohl, A., Rebmann, C., Freibauer, A., Mund, M., Ziegler, W., Kolle, O., and Schulze, E. D.: Forest and agricultural land-use-dependent $\mathrm{CO}_{2}$ exchange in Thuringia, Germany, Glob. Change Biol., 10, 2005-2019, 2004.

Aubinet, M., Chermanne, B., Vandenhaute, M., Longdoz, B., Yernaux, M., and Laitat, F.: Long term carbon dioxide exchange above a mixed forest in the Belgian Ardennes, Agr. Forest Meteorol., 108, 293-315, 2001.

Aumann, H. H., Chahine, M. T., Gautier, C., Goldberg, M. D., Kalnay, E., McMillin, L. M., Revercomb, H., Rosenkranz, P. W., Smith, W. L., Staelin, D. H., Strow, L., L., and Susskind, J.: AIRS/AMSU/HSB on the aqua mission: design, science objectives, data products and processing systems, IEEE T. Geosci. Remote, 41, 253-264, 2003.

Baker, J. M. and Baker, D. G.: Long-term ground heat flux and heat storage at a mid-latitude site, Climatic Change, 54, 295303, 2002.

Baldocchi, D. D., Falge, E., Gu, L., Olson, R., Hollinger, D., Running, S., Anthoni, P., Bernhofer, C., Davis, K., Evans, R., Fuentes, J., Goldstein, A., Katul, G., Law, B., Lee, X., Malhi, Y., Meyers, T., Munger, W., Oechel, W., Paw U, K. T., Pilegaard, K., Schmid, H. P., Valentini, R., Verma, S., Vesala, T., Wilson, K., and Wofsy, S.: Fluxnet: a new tool to study the temporal and spatial variability of ecosystem-scale carbon dioxide, water vapor, and energy flux densities, B. Am. Meteorol. Soc., 82, 24153434, 2001.

Baldocchi, D. D., Xu, L. K., and Kiang, N.: How plant functionaltype, weather, seasonal drought, and soil physical properties alter water and energy fluxes of an oak-grass savanna and an annual grassland, Agr. Forest Meteorol., 123, 13-39, 2004.

Bastiaanssen, W. G. M., Menenti, M., Feddes, R. A., and Holtslag, A. A. M.: The Surface Energy Balance Algorithm for Land (SEBAL): Part 1 formulation, J. Hydrol., 212-213, 198-212, 1998.

Batra, N., Islam, S., Venturini, V., Bisht, G., and Jiang L.: Estimation and comparison of evapotranspiration from MODIS and 
AVHRR sensors for clear sky days over the southern great plains, Remote Sens. Environ., 103, 1-15, 2006.

Betts, A. K., Ball, J. H., and Beljaars, A. C. M.: Comparison between the land surface response of the ECMWF model and the FIFE-1987 data, Q. J. Roy. Met. Soc., 119, 975-1001, 1993.

Bhattacharya, B. K., Mallick, K., Patel, N. K., and Parihar, J. S.: Regional clear sky evapotranspiration over agricultural land using remote sensing data from Indian geostationary meteorological satellite, J. Hydrol., 387, 65-80, 2010.

Bhattacharya, B. K., Mallick, K., Nigam, R., Dakore, K. K, and Sheikh, A. M.: Efficiency based wheat yield prediction in a semiarid climate using surface energy budgeting with satellite observations, Agr. Forest Meteorol., 151, 1394-1408, 2011.

Bindi, M., Miglietta, F., and Zipoli, G.:, Different methods for separating diffuse and direct components of solar radiation and their application in crop growth models, Climate Res., 2, 47 -54, 1992.

Bisht, G., Venturini, V., Islam, S., and Jiang, L.: Estimation of Net Radiation Using MODIS (Moderate Resolution Imaging Spectroradiometrer) Terra data for clear sky days, Remote Sens. Environ., 97, 52-67, 2005.

Bisht, G. and Bras, R.: Estimation of net radiation from the MODIS data under all sky conditions: Southern Great Plains case study, Remote Sens. Environ., 114, 1522-1534, 2010.

Bisht, G. and Bras, R. L.: Estimation of net radiation from the Moderate Resolution Imaging Spectroradiometer over the Continental United States, IEEE T. Geosci. Remote, 49, 2448-2462, 201, doi:10.1109/TGRS.2010.2096227, 2011.

Bounoua, L., Hall, F. G., Sellers, P. J., Kumar, A., Collatz, G. J., Tucker, C. J., and Imhoff, M. L.: Quantifying the negative feedback of vegetation to greenhouse warming: A modeling approach, Geophys. Res. Lett., 37, L23701, doi:10.1029/2010GL045338, 2010.

Bowen, I. S.: The ratio of heat losses by conduction and by evaporation from any water surface, Phy. Rev., 27, 779-787, 1926.

Cai, G., Xue, Y., Hu, Y., Guo, J., Wang, Y., and Qi, S.: Quantitative study of net radiation from MODIS data in the lower boundary layer in Poyang Lake area of Jiangxi Province, China, Int. J Remote Sens., 28, 4381-4389, 2007.

Cano, D., Monget, J. M., Albuisson, M., Guillard, H., Regas, N., and Wald, L.: A method for the determination of the global solar radiation from meteorological satellite data, Sol. Energy, 37, 3139, 1986.

Carswell, F. E., Costa, A. L., Palheta, M., Malhi, Y., Meir, P., Costa, J. D. R., Ruivo, M. D., Leal, L. D. M., Costa, J. M. N., Clement, R. J., and Grace, J.: Seasonality in $\mathrm{CO}_{2}$ and $\mathrm{H}_{2} \mathrm{O}$ flux at an eastern Amazonian rain forest, J. Geophys. Res.-Atmos., 107, D208076, doi:10.1029/2000JD000284, 2002.

Chen, M., Zhuang, Q., and He, Y.: An Efficient Method of Estimating Downward Solar Radiation Based on the MODIS Observations for the Use of Land Surface Modeling, Remote Sens., 6, 7136-7157, doi:10.3390/rs6087136, 2014.

Chen, X., Huang, X., Loeb, N.G., and Wei, H.: Comparisons of Clear-Sky Outgoing Far-IR Flux Inferred from Satellite Observations and Computed from the Three Most Recent Reanalysis Products, J. Climate, 26, 478-494, doi:10.1175/JCLI-D-1200212.1, 2013.

Choudhury, B. J.: Relationships between vegetation indices, radiation absorption, and net photosynthesis evaluated by a sensitivity analysis, Remote Sens. Environ., 22, 209-233, 1987.
Choudhury, B. J.: Estimating gross photosynthesis using satellite and ancillary data: approach and preliminary results, Remote Sens. Environ., 75, 1-21, 2001.

Cook, B. D., Davis, K. J., Wang, W., Desai, A., Berger, B. W., Teclaw, R. M., Martin, J. G., Bolstad, P. V., Bakwin, P. S., Yi, C., and Heilman, W.: Carbon exchange and venting anomalies in an upland deciduous forest in northern Wisconsin, USA, Agr. Forest Meteorol., 126, 271-295, 2004.

Corbari, C., Sobrino, J. A., Mancini, M., and Hidalgo, V.: Land surface temperature representativeness in a heterogeneous area through a distributed energy-water balance model and remote sensing data, Hydrol. Earth Syst. Sci., 14, 2141-2151, doi:10.5194/hess-14-2141-2010, 2010.

de Araújo, A. C., Nobre, A. D., Kruijt, B., Elbers, J. A., Dallarosa, R., Stefani, P., von Randow, C., Manzi, A. O., Culf, A. D., Gash, J. H. C., Valentini, R., and Kabat., P.: Comparative measurements of carbon dioxide fluxes from two nearby towers in a central Amazonian rainforest: the Manaus LBA site, J. Geophys. Res. Atmos., 107, 8090, doi:10.1029/2001JD000676, 2002.

Dubayah, R. and Loechel, S.: Modeling Topographic solar radiation using GOES data, J. Appl. Meteorol., 36, 141-154, 1997.

Fischer, M. L., Billesbach, D. P., Berry, J. A., Riley, W. J., and Torn, M. S.: Spatiotemporal variations in growing season exchanges of $\mathrm{CO}_{2}, \mathrm{H}_{2} \mathrm{O}$, and sensible heat in agricultural fields of the Southern Great Plains, Earth Int., 11, 1-21, 2007.

Foken, T.: The energy balance closure problem: an overview, Ecol. Appl., 18, 1351-1367, 2008.

Foken, T., Wimmer, F., Mauder, M., Thomas, C., and Liebethal, C.: Some aspects of the energy balance closure problem, Atmos. Chem. Phys., 6, 4395-4402, doi:10.5194/acp-6-4395-2006, 2006.

Fouquart, Y. and Bonnel, B.: Computations of solar heating of the earth's atmosphere: A new parameterization, Beitr. Phys. Atmos., 53, 35-62, 1980.

Gao, J. and Wu, S.: Simulated Effects of Land Cover Conversion on the Surface Energy Budget in the Southwest of China, Energies, 7, 1251-1264, doi:10.3390/en7031251, 2014.

Gao, W., Coulter, R. L., Lesht, B. M., Qiu, J., and Wesely, M. L.: Estimating clear-sky regional surface fluxes in the southern great plains atmospheric radiation measurement site with ground measurements and satellite observations, J. Appl. Meteorol., 37, 522,1998

Gentine, P., Entekhabi, D., Chehbouni, A., Boulet, G., and Duchemin, B.: Analysis of evaporative fraction diurnal behaviour, Agr. Forest Meteorol., 143, 13-29, 2007.

Giambelluca, T. W., Hölscher, D., Bastos, T. X., Frazão, R. R., Nullet, M. A., and Zeigler, A. D.: Observations of albedo and radiation balance over postforest land surfaces in the eastern Amazon Basin, J. Climate, 10, 919-928, 1997.

Gilmanov, T. G., Soussana, J. F., Aires, L., Allard, V., Ammann, C., Balzarolo, M., Barcza, Z., Bernhofer, C., Campbell, C. L., Cernusca, A., Cescatti, A., Brown, J. C., Dirks, O. M., Dore, S., Eugster, W., Fuhrer, J., Gimeno, C., Gruenwald, T., Haszpra, L., Hensen, A., Ibrom, A., Jacobs, A. F. G., Jones, M. B., Lanigan, G., Laurila, T., Ohila, A., Manca, G., Marcolla, B., Nagy, Z., Pilegaard, K., Pinter, K., Pio, C., Raschi, A., Rogiers, N., Sanz, M. J., Stefani, P., Sutton, M., Tuba, Z., Valentini, R., Williams, M. L., and Wohlfahrt, G.: Partitioning European grassland net ecosystem $\mathrm{CO}_{2}$ exchange into gross primary productivity and ecosys- 
tem respiration using light response function analysis, Agric. Ecosys. Environ., 121, 93-120, 2007.

Goldstein, A. H., Hultman, N. E., Fracheboud, J. M., Bauer, M. R., Panek, J. A., Xu, M., Qi, Y., Guenther, A. B., and Baugh, W.: Effects of climate variability on the carbon dioxide, water, and sensible heat fluxes above a ponderosa pine plantation in the Sierra Nevada (CA), Agr. Forest Meteorol., 101, 113-129, 2000.

Gough, C. M., Flower, C. E., Vogel, C. S. Dragoni, D., and Curtis, P. S.: Whole-ecosystem labile carbon production in a north temperate deciduous forest, Agr. Forest Meteorol., 149, 1531-1540, 2009.

Goulden, M. L., Miller, S. D., and da Rocha, H. R., Menton, M. C., De Freitas, H. C., Figuera, A. M. E. S., and De Sousa, C. A. D.: Diel and seasonal patterns of tropical forest $\mathrm{CO}_{2}$ exchange, Ecol. Appl., 14, S42-S54, 2004.

Granier, A., Loustau, D., and Breda, N.: A generic model of forest canopy conductance dependent on climate, soil water availability and leaf area index, Ann. For. Sc., 57, 755-765, 2000a.

Granier, A., Biron, P., and Lemoine, D.: Water balance, transpiration and canopy conductance in two beech stands, Agr. Forest Meteorol., 100, 291-308, 2000b.

Gubler, S., Gruber, S., and Purves, R. S.: Uncertainties of parameterized surface downward clear-sky shortwave and allsky longwave radiation., Atmos. Chem. Phys., 12, 5077-5098, doi:10.5194/acp-12-5077-2012, 2012.

Gueymard, C.: Direct solar transmittance and irradiance predictions with broadband models. Part I: detailed theoretical performance assessment, Sol. En., 74, 355-379, 2003.

Hammerle, A., Haslwanter, A., Tappeiner, U., Cernusca, A., and Wohlfahrt, G.: Leaf area controls on energy partitioning of a temperate mountain grassland, Biogeosciences, 5, 421-431, doi:10.5194/bg-5-421-2008, 2008.

Hearty, T. J., Savtchenko, A., Tian, B., Fetzer, E., Yung, Y. L., Theobald, M., Vollmer, B., Fishbein, E., and Won, Y.: Estimating sampling biases and measurement uncertainties of AIRS/AMSU-A temperature and water vapor observations using MERRA reanalysis, J. Geophys. Res. Atm., 119, 2725-2741, doi:10.1002/2013JD021205, 2014.

Heitman, J. L., Horton, R., Sauer, T .J., Ren, T. S., and Xiao, X.: Latent heat in soil heat flux measurements, Agr. Forest Meteorol., 150, 1147-1153, 2010.

Hildebrandt, A., Aufi, M. A., Amerjeed, M., Shammas, M., and Eltahir, E. A. B.: Ecohydrology of a seasonal cloud forest in Dhofar: 1. Field experiment, Water Resour. Res., 43, W10411, doi:10.1029/2006WR005261, 2007.

Hirano, T., Hirata, R., Fujinuma, Y., Saigusa, N., Yamamoto, S., Harazono, Y., Takada, M., Inukai, K., and Inoue, G.: $\mathrm{CO}_{2}$ and water vapor exchange of a larch forest in northern Japan, Tellus B, 55, 244-257, 2003.

Hirano, T., Segah, H., Harada, T., Limin, S., June, T., Hirata, R., and Osaki, M.: Carbon dioxide balance of a tropical peat swamp forest in Kalimantan, Indonesia, Glob. Change Biol., 13, 412425, 2007

Hollinger, D. Y., Goltz, S. M., Davidson, E. A., Lee, J. T., Tu, K., and Valentine, H. T.: Seasonal patterns and environmental control of carbon dioxide and water vapour exchange in an ecotonal boreal forest, Glob. Change Biol., 5, 891-902, 1999.
Hou, J., Jia, G., Zhao, T., Wang, H., and Tang, B.: Satellite based estimation of daily average net radiation under clear sky conditions, Adv. Atmos. Sci., 31, 705-720, 2014.

Huang, G. H., Liu, S. M., and Liang, S. L.: Estimation of net surface shortwave radiation from MODIS data, Int. J. Remote Sens., 33, 804-825, 2012.

Huang, G., Ma, M., Liang, S., Liu, S., and Li, X.: A LUT ${ }^{\circledR}$ approach to estimate surface solar irradiance by combining MODIS and MTSAT data, J. Geophys. Res., 116, D22201, doi:10.1029/2011JD016120, 2011.

Humes, K. S., Kustas, W. P., and Moran, M. S.: Use of remote sensing and reference site measurements to estimate instantaneous surface energy balance components over a semiarid rangeland watershed, Water Resour. Res., 30, 1363-1373, 1994.

Hutyra, L. R., Munger, J. W., Saleska, S. R., Gottlieb, E., Daube, B. C., Dunn, A. L., Amaral, D. F., de Camargo, P. B., and Wofsy, S. C.: Seasonal controls on the exchange of carbon and water in an Amazonian rain forest, J. Geophys. Res., 112, G03008, doi:10.1029/2006JG000365, 2007.

Hsieh C. I., Huang, C. W., and Kiely, G.: Long term estimation of soil heat flux by single layer soil temperature, Int. J. Biometeorol., 53, 113-123, 2009.

Hwang K., Choi, M., Lee, S. O., and Seo, J.-W.: Estimation of instantaneous and daily net radiation from MODIS data under clear sky conditions: a case study in East Asia, Irrig. Sci., 31, 11731184, doi:10.1007/s00271-012-0396-3, 2013.

Jacobs, J. M., Anderson, M. C., Friess, L. C., and Diak, G. R.: Solar radiation, longwave radiation and emergent wetland evapotranspiration estimates from satellite data in Florida, USA, Hydrol. Sc., 49, 461-176, 2004.

Jaksic, V., Kiely, G., Albertson, J., Katul, G., and Oren, R.: Net ecosystem exchange of grassland in contrasting wet and dry years, Agr. Forest Meteorol., 139, 323-334, 2006.

Jin, Y., Randerson, J. T., and Goulden, M. L.: Continental-scale net radiation and evapotranspiration estimated using MODIS satellite observations, Remote Sens. Environ., 115, 2302-2319, 2011.

Jin, Z., Charlock, T. P., Smith Jr., W. L., and Rutledge, K.: A parameterization of ocean surface albedo, Geophys. Res. Lett., 31, L22301, doi:10.1029/2004GL021180, 2004.

Katul, G. G., Leuning, R., and Oren, R.: Relationship between plant hydraulic and biochemical properties derived from a steady-state coupled water and carbon transport model, Pl. Cell Environ., 26, 339-350, 2003.

Kaufmann, Y. J. and Koran, I.: Smoke and Pollution Aerosol Effect on Cloud Cover, Science, 313, 655-658, 2006.

Kergoat, L., Grippa, M., Baille, A., Eymard, L., Lacaze, R., Mougin, E., Ottlé, C., Pellarin, T., Polcher, J. Rosnay, P. de., Roujean, J. -L., Sandholt, I., Taylor, C. M., Zin, I., and Zribi, M.: Remote sensing of the land surface during the African Monsoon Multidisciplinary Analysis (AMMA), Atmos. Sci. Lett., 12, 129-134, 2011.

Kim, J. and Hogue, T. S., Evaluation of a MODIS-based potential evapotranspiration product at the point-scale, J. Hydrometeorol., 9, 444-460, 2008.

Kustas, W. P. and Norman, J. M.: Evaluating the Effects of Subpixel Heterogeneity on Pixel Average Fluxes, Remote Sens. Environ., 74, 327-342, 2000. 
Lakshmi, V. and Zehrfuhs, D.: Normalization and comparison of surface temperatures across a range of scales, IEEE T. Geosci. Remote 40, 2636-2646, 2002.

Li, J. and Islam, S.: On the estimation of soil moisture profile and surface fluxes partitioning from sequential assimilation of surface layer soil moisture, J. Hydrol., 220, 86-103, 1999.

Liang, S., Strahler, A. H., and Walthall, C.: Retrieval of land surface albedo from satellite observations: A simulation study, J. Appl. Meteorol., 38, 712-725, 1999.

Liang, S., Shuey, C., Russ, A., Fang, H., Chen, M., Walthall, C., and Daughtry, C.: Narrowband to Broadband Conversions of Land Surface Albedo: II. Validation, Remote Sens. Environ., 84, 2541, 2002.

Liang, X., Wood, E. F., Lettenmaier, D. P., Lohmann, D., Boone, A., Chang, S., Chen, F., Dai, Y., Desborough, C., Dickinson, R. F., Duan, Q., Ek, M., Gusev, Y. M., Habets, F., Irannejad, P., Koster, R., Mitchell, K. E., Nasonova, O. N., Noilhan, J., Schaake, J., Schlosser, A., Shao, Y., Shmakin, A. B., Verseghy, D., Warrach, K., Wetzel, P., Xue, Y., Yang, Z. -L., and Zeng, Q.: The Project for Intercomparison of Land-surface Parameterization Schemes (PILPS) phase 2 (c) Red-Arkansas River basin experiment: 2. Spatial and temporal analysis of energy fluxes, Glob. Planet. Change, 19, 137-159, 1998.

Lin, B., Stackhouse Jr., P. W., Minnis, P., Wielicki, B. A., Hu, Y., Sun, W., Fan, T.-F., and Hinkelman, L. M.: Assessment of global annual atmospheric energy balance from satellite observations, J. Geophys. Res., 113, D16114, doi:10.1029/2008JD009869, 2008.

Liu, Z., Vavrus, S., He, F., Wen, N., and Zhong, Y.: Rethinking tropical ocean response to global warming: the enhanced equatorial warming, J. Climate, 18, 4684-4700, 2005.

Longman, R. J., Giambelluca, T. W., and Frazier, A. G.: Modeling clear-sky solar radiation across a range of elevations in Hawai' $i$ : Comparing the use of input parameters at different temporal resolutions, J. Geophys. Res., 117, D02201, doi:10.1029/2011JD016388, 2012.

Ma, Y., Su, Z., Li, Z., Koike, T., and Menenti, M.: Determination of regional net radiation and soil heat flux over a heterogeneous landscape of the Tibetan Plateau, Hydrol. Process., 16, 29632971, 2002.

Mallick, K., Bhattacharya, B. K., Rao, V. U. M., Reddy, D. R., Banerjee, S., Hoshali, V., Pandey, V., Kar, G., Mukherjee, J., Vyas, S. P., Gadgil, A. S., and Patel, N. K.: Latent heat flux estimation in clear sky days over Indian agroecosystems using noontime satellite remote sensing data, Agr. Forest Meteorol., 149, 1646-1665, 2009.

Mallick, K., Jarvis, A. J., Boegh, E., Fisher, J. B., Drewry, D. T., Tu, K. P., Hook, S. J., Hulley, G., Ardo, J., Beringer, J., Arain, A., and Niyogi, D.: A surface temperature initiated closure (STIC) for surface energy balance fluxes, Remote Sens. Environ., 141, 243-261, 2014a.

Mallick, K., Jarvis, A., Wohlfahrt, G., Kiely, G., Hirano, T., Miyata, A., Yamamoto, S., and Hoffmann, L.: Components of nearsurface energy balance derived from satellite soundings - Part 2: Noontime latent heat flux, Biogeosciences, 11, 7369-7382, doi:10.5194/bg-11-7369-2014, 2014b.

Mamadou, O., Cohard, J. M., Galle, S., Awanou, C. N., Diedhiou, A., Kounouhewa, B., and Peugeot, C.: Energy fluxes and surface characteristics over a cultivated area in Benin: daily and seasonal dynamics, Hydrol. Earth Syst. Sci., 18, 893-914, doi:10.5194/hess-18-893-2014, 2014.

Massaquoi, J. G. M.: Global solar radiation in Sierra Leone (West Africa), Solar Wind Tech., 5, 281-283, 1988.

Mayocchi, C. L. and Bristow, K. L.: Soil surface heat flux: some general questions and comments on measurements, Agr. Forest Meteorol., 75, 43-50, 1995.

Mecikalksi, J. R., Diak, G. R., Anderson, M. C., and Norman, J. M.: Estimating fluxes on continental scales using remotely-sensed data in an atmospheric-land exchange model, J. Appl. Meteorol., 35, 1352-1369, 1999.

Meyers, T. P. and Hollinger, S. E.: An assessment of storage terms in the surface energy balance of maize and soybean, Agr. Forest Meteorol., 125, 105-115, 2004.

Miglietta, F., Gioli, B., Brunet, Y., Hutjes, R. W. A., Matese, A., Sarrat, C., and Zaldei, A.: Sensible and latent heat flux from radiometric surface temperatures at the regional scale: methodology and evaluation, Biogeosciences, 6, 1975-1986, doi:10.5194/bg6-1975-2009, 2009.

Mlawer, E. J., Taubman, S. J., Brown, P. D., Iacono, M. J., and Clough, S. A.: Radiative transfer for inhomogeneous atmosphere: RRTM, a validated correlated- $k$ model for the longwave, J. Geophys. Res., 120D, 16663-16682, 1997.

Mlynczak, P. E., Smith, G. L., and Doelling, D. R.: The annual cycle of Earth radiation budget from Clouds and the Earth's Radiant Energy System (CERES) data, J. Appl. Meteorol. Clim., 50, 2490-2503, doi:10.1175/JAMC-D-11-050.1, 2011.

Monteith, J. L.: Evaporation and environment, Symp. Soc. Exp. Biol., 19, 205-234, 1965.

Morcrette, J. J.: Assessment of the ECMWF model cloudiness and surface radiation fields at the ARM SGP site, Month. Weather Rev., 130, 257-277, 2002.

Mu, Q., Heinsch, F. A., Zhao, M., and Running, S. W.: Development of a global evapotranspiration algorithm based on MODIS and global meteorology data, Remote Sens. Environ., 111, 519-536, 2007.

Mu, Q., Zhao M., and Running S. W.: Improvements to a MODIS Global Terrestrial Evapotranspiration Algorithm, Remote Sens. Environ., 115, 1781-1800, 2011.

Murray, T. and Verhoef, A.: Moving towards a more mechanistic approach in the determination of soil heat flux from remote measurements - I. A universal approach to calculate thermal inertia, Agr. Forest Meteorol., 147, 80-87, doi:10.1016/j.agrformet.2007.07.004, 2007.

Niemela, S., Raisanen, P., and Savijarvi, H.: Comparison of surface radiative flux parameterizations Part I: Longwave radiation, Atmos. Res., 58, 1-18, 2001.

Ochsner, T. E., Sauer, T. J., and Horton, R.: Soil heat storage measurements in energy balance studies, Agron. J., 99, 311-319, 2007.

Oliphant, A. J., Spronken-Smith, R. A., Sturman, A. P., and Owens, I. F.: Spatial Variability of Surface Radiation Fluxes in Mountainous Terrain, J. Appl. Meteorol., 42, 113-128, 2003.

Peng, J., Liu, Y., Zhao, X., and Loew, A.: Estimation of evapotranspiration from MODIS TOA radiances in the Poyang Lake basin, China, Hydrol. Earth Syst. Sci., 17, 1431-1444, doi:10.5194/hess-17-1431-2013, 2013.

Penman, H. L.: Natural evaporation from open water, bare soil and grass, Proc. Roy. Soc. London, A193, 120-145, 1948. 
Pinker, R. T. and Laszlo, I.: Modeling Surface Solar irradiance for satellite applications on a global scale, J. Appl. Meteorol., 31, 194-211, 1992.

Prata, A. J.: A new long-wave formula for estimating downward clear-sky radiation at the surface, Q. J. R. Meteorol. Soc., 122, 1127-1151, 1996.

Priestley, K. J., Smith, G. L., Thomas, S., Cooper, D., Lee, R. B., Walikainen, D., Hess, P., Szewczyk, Z. P., and Wilson, R.: Radiometric Performance of the CERES Earth Radiation Budget Climate Record Sensors on the EOS Aqua and Terra Spacecraft through April 2007, J. Atmos. Ocean. Tech., 28, 3-21, doi:10.1175/2010JTECHA1521.1, 2011.

Quaas, J., Stevens, B., Stier, P., and Lohmann, U.: Interpreting the cloud cover - aerosol optical depth relationship found in satellite data using a general circulation model, Atmos. Chem. Phys., 10, 6129-6135, doi:10.5194/acp-10-6129-2010, 2010.

Reichstein, M., Tenhunen, J., Roupsard, O., Ourcival, J. M., Rambal, S., Miglietta, F., Peressotti, A., Pecchiari, M., Tirone, G., and Valentini, R.: Inverse modeling of seasonal drought effects on canopy $\mathrm{CO}_{2} / \mathrm{H}_{2} \mathrm{O}$ exchange in three Mediterranean ecosystems, J. Geophys. Res.-Atmos., 108, D23, doi:10.1029/2003JD003430, 2003.

Ryu, Y., Kang, S., Moon, S. K., and Kim, J.: Evaluation of land surface radiation balance derived from moderate resolution imaging spectroradiometer (MODIS) over complex terrain and heterogeneous landscape on clear sky days, Agr. Forest Meteorol., 148, 1538-1552, 2008.

Saigusa, N. Yamamoto, S., Murayama, S., Kondo, H., and Nishimura, N.: Gross primary production and net ecosystem exchange of a cool- temperate deciduous forest estimated by the eddy covariance method, Agr. Forest Meteorol., 112, 203-215, 2002.

Saito, M., Miyata, A., Nagai, H., and Yamada, T.: Seasonal variation of carbon dioxide exchange in rice paddy field in Japan, Agr. Forest Meteorol., 135, 93-109, 2005.

Salomon, J. G., Schaff, C. B., Strahler, A. H., Gao, F., and Jin, Y. F.: Validation of the MODIS bidirectional reflectance distribution function and albedo retrievals using combined observations from the Aqua and Terra platforms, IEEE T. Geosci. Remote, 44, 1555-1565, 2006.

Santanello, Jr., J. A. and Friedl, M. A.: Diurnal Covariation in Soil Heat Flux and Net Radiation, J. Appl. Meteorol., 42, 851-862, 2003.

Sauer, T. J. and Horton R.: Soil heat flux, in: Micrometeorology in Agricultural Systems, edited by: Hatfield, J. L. and Baker, J. M., Am. Soc. Agr., Madison, Wisconsin, USA, 131-154, 2005.

Scholes, R. J., Gureja, N., Giannecchinni, M., Dovie, D., Wilson, B., Davidson, N., Piggott, K., McLoughlin, C., van der Velde, K., Freeman, A., Bradley, S., Smart, R., and Ndala, S.:. The environment and vegetation of the flux measurement site near Skukuza, Kruger National Park, Koedoe, 44, 73-83, 2001.

Schwartz, S. E.: Heat capacity, time constant, and sensitivity of Earth's climate system, J. Geophys. Res., 112, D24S05, doi:10.1029/2007JD008746, 2007.

Seidel, F. C., Kokhanovsky, A. A., and Schaepman, M. E.: Fast and simple model for atmospheric radiative transfer, Atmos. Meas. Tech., 3, 1129-1141, doi:10.5194/amt-3-1129-2010, 2010.

Stackhouse, P. W., Gupta, S. K., Cox, S. J., Chiacchio, M., and Mikovitz, J. C.: The WCRP/GEWEX Surface Radiation Budget
Project Release 2: An assessment of surface fluxes at $1^{\circ}$ resolution, edited by: Smith, W. L. and Timofeyev, Y. M., IRS 2000: Current problems in atmospheric radiation, International Radiation Symposium, St. Petersburg, Russia, 24-29, 2000.

Stephens, G. L., Wild, M., Stackhouse, P. W., L'Ecuyer, T., Kato, S., and Henderson, D. S.: The Global Character of the Flux of Downward Longwave Radiation, J. Climate, 25, 2329-2340, doi:10.1175/JCLI-D-11-00262.1, 2012.

Stisen, S., Sandholt, I., Nørgaard, A., Fensholt, R., and Jensen, K. H.: Combining the triangle method with thermal inertia to estimate regional evapotranspiration applied to MSG-SEVIRI data in the Senegal river basin, Remote Sens. Environ., 112, 1242 1255, 2008.

Stoy, P. C., Mauder, M., Foken, T., Marcolla, B., Boegh, E., Ibrom, A., Arain, M. A., Arneth, A., Aurela, M., Bernhofer, C., Cescatti, A., Dellwik, E., Duce, P., Gianelle, D., van Gorsel, E., Kiely, G., Knohl, A., Margolis, H., McCaughey, H., Merbold, L., Montagnani, L., Papale, D., Reichstein, M., Saunders, M., Serrano-Ortiz, P., Sottocornola, M., Spano, D., Vaccari, F., Varlagin, A.: A data-driven analysis of energy balance closure across FLUXNET research sites: The role of landscape scale heterogeneity, Agr. Forest Meteorol., 171-172, 137-152, doi:10.1016/j.agrformet.2012.11.004, 2013.

Stramma, L., Cornillon, P., Weller, R. A., Price, J. F., and Briscoe, M. G.: Large diurnal sea surface temperature variability: satellite and in situ measurements, J. Geophys. Res., 16, 827-837, 1986.

Sultan, S., Wu, R., and Ahmed, I..: Impact of Terrain and Cloud Cover on the Distribution of Incoming Direct Solar Radiation over Pakistan, J. Geogr. Inform. Sys., 6, 70-77, doi:10.4236/jgis.2014.61008, 2014.

Sun, Z., Gebremichael, M., Wang, Q., Wang, J., Sammis, T. W., and Nickless, A.: Evaluation of Clear-Sky Incoming Radiation Estimating Equations Typically Used in Remote Sensing Evapotranspiration Algorithms, Remote Sens., 5, 4735-4752; doi:10.3390/rs5104735, 2013.

Tang, B., Li, Z.-L., and Zhang, R.: A direct method for estimating net surface shortwave radiation from MODIS data, Remote Sens. Environ., 103, 115-126, doi:10.1016/j.rse.2006.04.008, 2006.

Tamai, K., Abe, T., Araki, M., and Ito, H.: Radiation budget, soil heat flux and latent heat flux at the forest floor in warm, temperate mixed forest, Hydrol. Proc., 12, 2105-2114, 1998.

Thornton, P. E. and Running, S. W.: An improved algorithm for estimating incident daily solar radiation from measurements of temperature, humidity, and precipitation, Agr. Forest Meteorol., 93, 211-228, 1999.

Tittebrand, A. and Berger, F. H.: Spatial heterogeneity of satellite derived land surface parameters and energy flux densities for LITFASS-area, Atmos. Chem. Phys., 9, 2075-2087, doi:10.5194/acp-9-2075-2009, 2009.

Trenberth, K.: Changes in precipitation with climate change, Clim. Res., 47, 123-138, doi:10.3354/cr00953, 2011.

Trenberth, K., Fasullo, J., and Kiehl, J.: Earth's global energy budget, Bull. Am. Meteor. Soc., 90, 311-323, doi:10.1175/2008BAMS2634.1, 2009.

Urbanski, S., Barford, C., Wofsy, S. Kucharik, C., Pyle, E., Budney, J., Fitzjarrald, D., Czikowsky, M., and Munger, J. W.: Factors Controlling $\mathrm{CO}_{2}$ Exchange at Harvard Forest on Hourly to Annual Time Scales, J. Geophys. Res., 112, G02020, doi:10.1029/2006JG000293, 2007. 
Verhoef, A., Ottle, C., Cappelaere, B., Murray, T., Saux-Picart, S., Zribi, M., Maignan, F., Boulain, N., Demarty, J., and Ramier, D.: Spatio-temporal surface soil heat flux estimates from satellite data: results for the AMMA experiment at the Fakara (Niger) supersite, Agr. Forest Meteorol., 154-155, 5566, doi:10.1016/j.agrformet.2011.08.003, 2012.

Verstraeten, W., Veroustraete, F., and Feyen, J.: Estimating evapotranspiration of European forests from NOAA-imagery at satellite overpass time: Towards an operational processing chain for integrated optical and thermal sensor data products, Remote Sens. Environ., 96, 256-276, 2005.

Wang, H. and Pinker, R. T., Shortwave radiative fluxes from MODIS: Model development and implementation, J. Geophys. Res., 114, D20201, doi:10.1029/2008JD010442, 2009.

Wielicki, B. A., Barkstrom, B. R., Baum, B. A., Charlock, T. P., Green, R. N., Kratz, D. P., Lee, R. B., Minnis, P., Smith, G. L., Wong, T. M., Young, D. F., Cess, R. D., Coakley, J. A., Crommelynck, D. A. H., Donner, L., Kandel, R., King, M. D., Miller, A. J., Ramanathan, V., Randall, D. A., Stowe, L. L., and Welch, R. M.: Clouds and the Earth's Radiant Energy System (CERES): Algorithm overview, IEEE Trans. Geosc. Remote Sens., 36, 1127-1141, 1998.
Wild, M., Folini, D., Schar, C., Loeb, N., Dutton, E. G., and Langlo, G. K.: The global energy balance from a surface perspective, Clim. Dynam., 40, 3107-3134, doi:10.1007/s00382-012-1569-8, 2013.

Wilson, K. B., Goldstein, A. H., Falge, E., Aubinet, M., Baldocchi, D., Berbigier, P., Bernhofer, Ch., Ceulemans, R., Dolman, H., Field, C., Grelle, A., Law, B., Meyers, T., Moncrieff, J., Monson, R., Oechel, W., Tenhunen, J., Valentini, R., and Verma, S.: Energy balance closure at FLUXNET sites, Agr. Forest Meteorol., 113, 223-243, 2002.

Wright, I. R., Gash, J. H. C., da Rocha, R., Shuttleworth, W. J., Nobre, C. A., Maitelli, G. T., Zamparoni, C. A. G. P., and Carvalho, P. R. A.: Dry season micrometeorology of central Amazonian ranchland, Q. J. Roy. Meteorol. Soc., 118, 1083-1099, 1992.

Zhang, J. H., Han, S. J., and Yu, G. R.: Seasonal variation in carbon dioxide exchange over a 200-year-old Chinese broad-leaved Korean pine mixed forest, Agr. Forest Meteorol., 137, 150-165, 2006. 